Florida International University FIU Digital Commons

\title{
Community-Governed Multifunctional Landscapes and Forest Conservation in the Sierra Norte of Oaxaca, Mexico
}

Barbara Pazos Almada

Florida International University, bpazo002@fiu.edu

DOI: $10.25148 /$ etd.FIDC000768

Follow this and additional works at: https://digitalcommons.fiu.edu/etd

Part of the Environmental Studies Commons, Forest Management Commons, Natural Resources and Conservation Commons, Natural Resources Management and Policy Commons, and the Sustainability Commons

\section{Recommended Citation}

Pazos Almada, Barbara, "Community-Governed Multifunctional Landscapes and Forest Conservation in the Sierra Norte of Oaxaca, Mexico" (2016). FIU Electronic Theses and Dissertations. 2554.

https://digitalcommons.fiu.edu/etd/2554 


\section{FLORIDA INTERNATIONAL UNIVERSITY}

Miami, Florida

COMMUNITY-GOVERNED MULTIFUNCTIONAL LANDSCAPES

AND FOREST CONSERVATION IN THE SIERRA NORTE OF OAXACA, MEXICO

A thesis submitted in partial fulfillment of

the requirements for the degree of

MASTER OF SCIENCE

in

ENVIRONMENTAL STUDIES

by

Barbara Pazos Almada 
To: Dean Michael R. Heithaus

College of Arts, Sciences and Education

This thesis, written by Barbara Pazos Almada, and entitled Community-Governed Multifunctional Landscapes and Forest Conservation in the Sierra Norte of Oaxaca, Mexico, having been approved in respect to style and intellectual content, is referred to you for judgment.

We have read this thesis and recommend that it be approved.

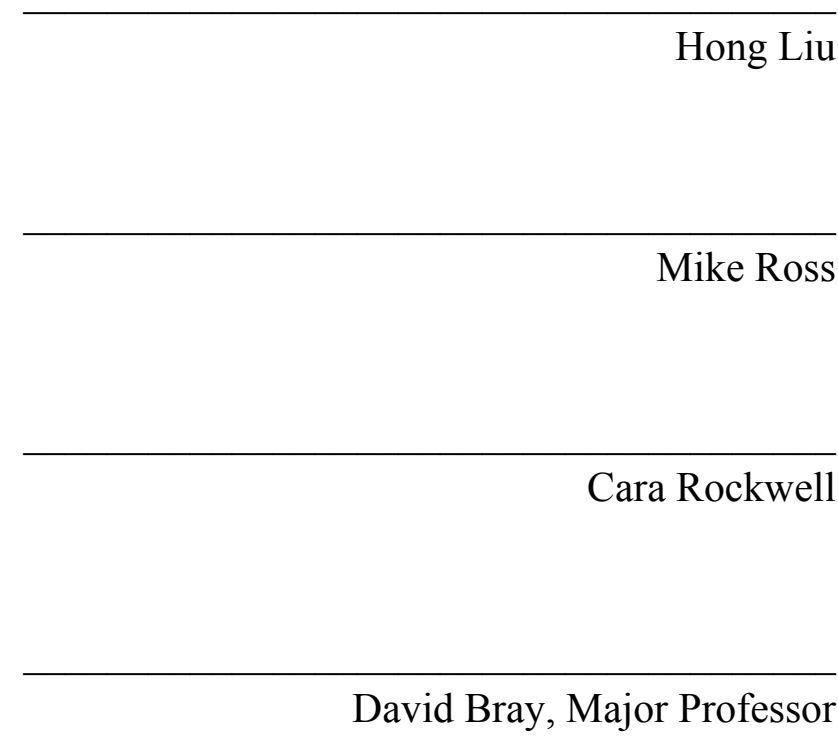

Date of Defense: July 7, 2016

The thesis of Barbara Pazos Almada is approved.

Dean Michael R. Heithaus

College of Arts, Sciences and Education

Andrés G. Gil

Vice President for Research and Economic Development and Dean of the University Graduate School

Florida International University, 2016 


\section{DEDICATION}

I dedicate this thesis to my mom and my sister, without whom I could never have done it. Their love and support were indispensable during this process. And to my family, in the US and in Brazil, who, from near and afar, always encouraged and motivated me. I am forever grateful for all the amazing people in my life. 


\section{ACKNOWLEDGMENTS}

I owe thanks, first and foremost, to my major advisor Dr. David Bray, for all the guidance and mentorship throughout my graduate career. Your help was simply invaluable. I thank my committee members, Dr. Cara Rockwell, Dr. Hong Liu, and Dr. Mike Ross, for the support and always being there for me! I am extremely thankful to Eric Betancourt, for being by my side every step of the way, and for helping me with words whenever they escaped me; I couldn't have done this without you. To my dear friend Emily Kroloff, for jumping with me on this roller coaster of emotions that was Grad School, and sharing all the crazy this journey brought us. I thank my "soulie", Ana Guzmán, for being the best "officemate" anyone could ever ask for! I'm so grateful for Nina De la Rosa, for all that you always do for me, and Nall Moonilall, for all the encouragement since day one. I'm also thankful for my friend David Riera, for always insisting I apply for grants until I did - thank you for always believing in me. I'd like to thank Tyler Stout, for helping me with Stats, Eric Van Vleet, for all the initial guidance, and Mustafa Sikder, Anteneh Z. Abiy and Jen Lopez, for the last minute help! A huge thank you to my awesome students, for being my favorite part about Grad School!

A special thanks to the people of CONAFOR and SEMARNAT, all Foresters, Comisariados, and community members in Sierra Norte, who were all so helpful during my time in Oaxaca. I would like to thank E\&E for granting me a Teaching Assistantship. Finally, I'm extremely grateful for all my friends and family (especially, always, my mama and sis), who understood whenever I couldn't be there because of school, and the ones who were on the same boat with me - We made it! Funding for travel was provided by the Tinker Foundation Grant and the Judith Evans Parker Scholarship. 


\author{
ABSTRACT OF THE THESIS \\ COMMUNITY-GOVERNED MULTIFUNCTIONAL LANDSCAPES AND FOREST \\ CONSERVATION IN THE SIERRA NORTE OF OAXACA, MEXICO \\ by \\ Barbara Pazos Almada
}

Florida International University, 2016

Miami, Florida

Professor David Bray, Major Professor

Community forestry is an evolving approach to forest management, shown to maintain forest cover, while generating income for local communities. In Sierra Norte (SN), a region with no public protected areas, indigenous communities have been actively conserving their forests for decades, through conservation zoning and careful management of their logging areas. This study found that across 22 communities in $\mathrm{SN}$, an estimated $2,949,116.50 \mathrm{~m}^{3}$ of timber were produced from 1993 to 2013, while the region maintains $78 \%$ forest cover. About $75 \%$ of the forest is under some form of community conservation. Community governance plays a major role, as rules and regulations regarding use, access, and conservation of communal lands are established and enforced by community members. The findings of this study support arguments that advocate for community forest management, as forest communities prove to maintain forest cover and decrease degradation, thus reducing greenhouse gas emissions and enhancing forest carbon stocks. 


\section{TABLE OF CONTENTS}

CHAPTER

PAGE

CHAPTER 1: Literature Review ……………………............................................. 1

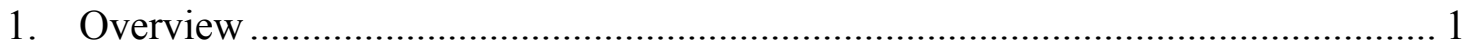

2. Common Property Regime and the Emergence of Mexican CFEs......................... 7

3. Deforestation in Mexico and Community Forestry ……...................................... 13

4. Community Forest Management and Climate Change ........................................ 15

5. Silvicultural Systems and Forest Conservation in Sierra Norte .............................. 18

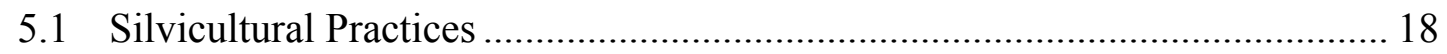

5.2 Land Sharing vs. Land Sparing ………………….................................... 22

5.3 Land-Use Zoning Practices and Forest Conservation in Sierra Norte.............. 24

CHAPTER 2: Logging and Community Conservation in Sierra Norte.............................. 30

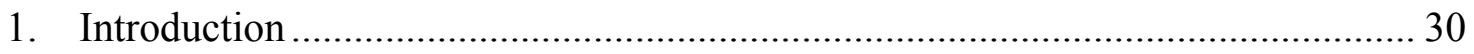

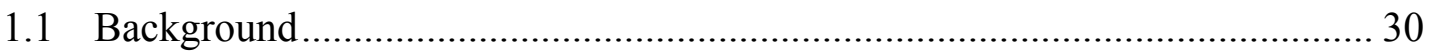

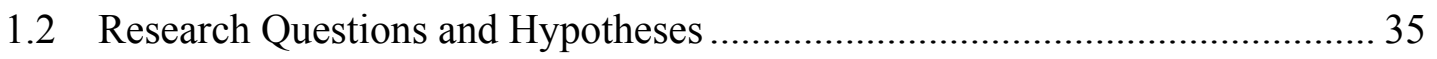

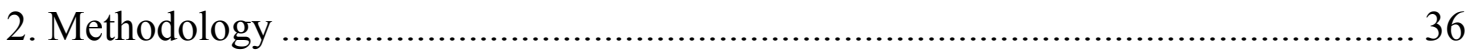

2.1 Study Area and Community Selection ……………………………………..... 36

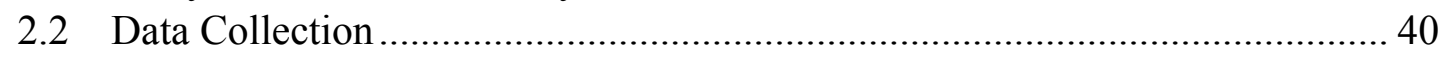

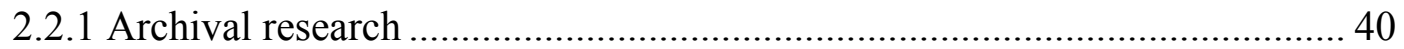

2.2.2 Semi-Structured Interviews and Community Visits ..................................... 42

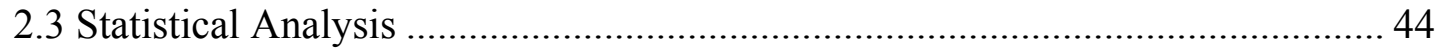

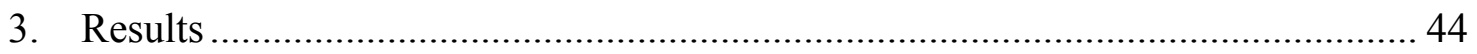

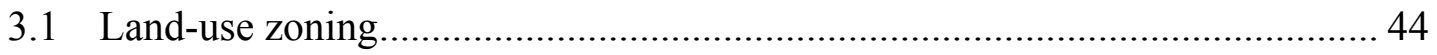

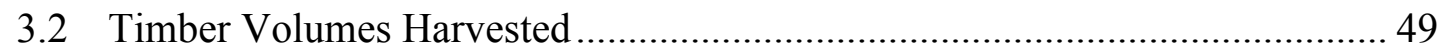

3.3 Statistical Analysis of Land Use and Timber Volumes................................... 52

3.3.1 Typology vs. Land Use and Timber Harvested ........................................... 52

3.3.2 Territory Size and Population Density vs. Land Use and

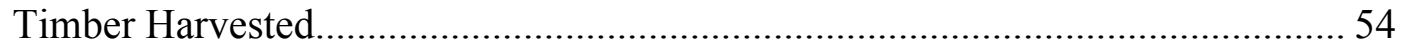

3.4 Management Practices and Conservation ........................................................ 56

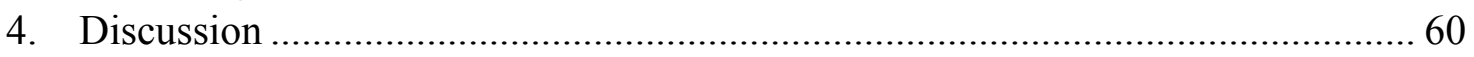

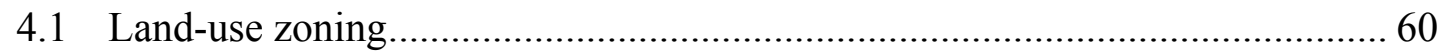

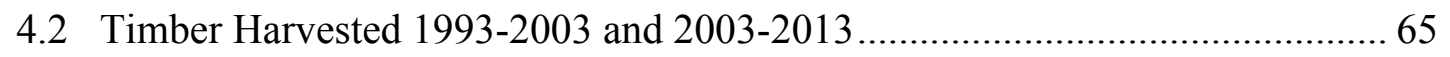

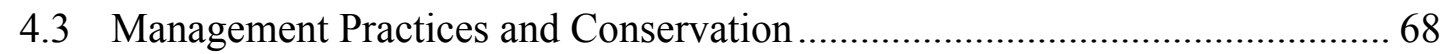

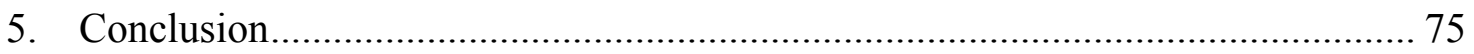

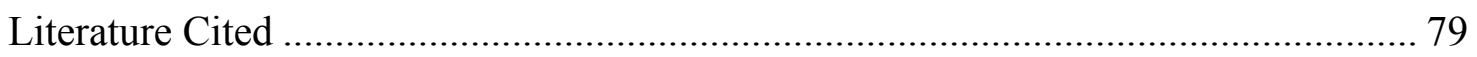

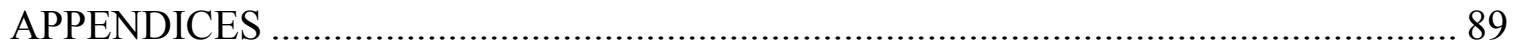




\section{LIST OF TABLES}

TABLE

PAGE

Table 1: History of Mexican Community Forestry $\ldots \ldots \ldots \ldots \ldots \ldots \ldots \ldots \ldots \ldots \ldots \ldots \ldots \ldots \ldots \ldots$

Table 2: Sierra Norte Communities ........................................... 38

Table 3: Mann-Whitney U and Kruskal-Wallis Tests Results ......................... 53

Table 4: ANOVA and Kruskal-Wallis Tests Results ............................... 54

Table 5: Spearman's Rank-Order Correlation Test Results .......................... 55

Table 6: Most and Least Intensive Logging ................................. 60

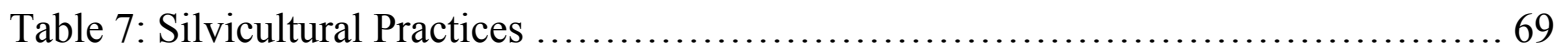




\section{LIST OF FIGURES}

FIGURE

PAGE

Figure 1: Asamblea General de Ejidatarios/Comuneros

(General Assembly of Rightsholders) ........................................... 10

Figure 2: Map of SNO Municipalities in the Study ........................... 40

Figure 3: Interview with Comisariado of San Juan Evangelista Analco ............... 42

Figure 4: San Juan Evangelista Analco Visit with Forester and CONAFOR ............ 43

Figure 5: One of 160+ seedlings I planted during a reforestation activity in San Juan Bautista Atepec ................................................ 44

Figure 6: Land-Use Totals ................................................... 45

Figure 7: Total Territory vs. Forested Areas (ha) ............................... 46

Figure 8: Percentages of Conservation and Production Areas ....................... 47

Figure 9: Production vs. Logged vs. Reserved (ha) $\ldots \ldots \ldots \ldots \ldots \ldots \ldots \ldots \ldots \ldots \ldots \ldots . \ldots \ldots$

Figure 10: Total Forest Under Conservation ................................ 49

Figure 11: Timber Volumes Harvested 1993-2003 and 2003-2013 $\left(\mathrm{m}^{3}\right)$................ 50

Figure 12: Timber Volumes Authorized and Harvested 1993-2003 ................ 51

Figure 13: Reasons for Logging Below Authorized Volumes ..................... 52

Figure 14: Payment for Ecosystem Services in SNO 2009-2013 .................. 57

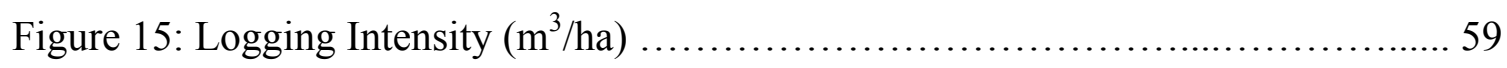

Figure 16: Volumes of Timber Produced in Oaxaca and Sierra Norte 2002-2011 _..... 67 


\section{ABBREVIATIONS AND ACRONYMS}

$\mathrm{CBC}$

CF

CFE

CFM

CONAFOR

CONANP

CPR

ERA

LGDFS

LUZ

MDS

MMOBI

NTFP

OTC

PSAH

PES
Comisariado de Bienes Comunales (Commission on Common Properties)

Community Forestry

Community Forest Enterprise

Community Forest Management

Comisión Nacional Forestal (National Forestry Commission)

Comisión Nacional de Áreas Naturales Protegidas (National Commission of Natural Protected Areas)

Common Pool Resources

Estudios Rurales y Asesoria (Rural Studies and Consulting)

Ley General del Desarrollo Forestal Sustentable de México (General Law on Sustainable Forestry Development)

Land-use Zoning

Método de Desarrollo Silvícola (Silvicultural Development Method)

Método Mexicano de Ordenacion de Bosques Irregulares (Mexican Method of Regulating Irregular Forests)

Non-Timber Forest Products

Ordenamiento Territorial Comunitário (Community Land-use zoning Plans)

Pago por Servícios Ambientales Hidrológicos (Payment for Hydrological Environmental Services)

Payments for Ecosystem Services 
PMF

PROCYMAF

PRODEFOR

PRODEPLAN

PROFEPA

PRONARE

REDD+

RIL

SEMARNAT

SICODESI

SNO

SRA

VCA
Programa de Manejo Forestal (Forest Management Plan)

Programa de Desarollo Forestal Comunitário (Program for Sustainable Community Forestry)

Programa de Desarrollo Forestal (Forestry Development Program)

Programa para el Desarrollo de Plantaciones Forestales

Comerciales (Program for the Development of Commercial Forest Plantations)

Procuraduría Federal de Protección al Ambiente (Federal Attorney General for Environmental Protection)

Programa Nacional de Reforestación (National Reforestation Program)

Reducing Emissions from Deforestation and Forest Degradation

Reduced Impact Logging

Secretaria de Medio Ambiente y Recursos Naturales (Secretariat of Environment and Natural Resources)

Sistema de Conservacion y Desarrollo Silvícola (Conservation and Silvicultural Development System)

Sierra Norte of Oaxaca

Secretaria de Reforma Agraria Nacional (National Agrarian Reform Secretariat)

Voluntary Conserved Areas 


\section{CHAPTER 1: Literature Review}

\section{Overview}

Deforestation is a major contributor to perhaps one of the biggest issues our planet faces at the moment: global climate change. Therefore, tactics to reduce deforestation and mitigate climate change are gaining attention worldwide. Deforestation and environmental degradation have also been linked with poverty, especially in rural areas of developing countries (Swanson 1998, Deininger and Minten 1999, Vosti and Reardon 2007, Macqueen 2007). More than half a billion people in the world rely on goods and services provided by forests to survive (Sunderlin et al. 2005, Chhatre and Agrawal 2009, Putz et al. 2012b).

Traditional conservation models, such as National Park Systems and other Protected Areas have shown to be effective to varying degrees in protecting forest ecosystems and the biodiversity within their borders (Bruner et al. 2001, Figueroa and Sanchez-Cordero 2008, Getzner et al. 2012). However, these management strategies have proven insufficient in meeting the needs and circumstances encountered in most developing countries, where many livelihoods are dependent on forestlands (Asbjornsen and Ashton 2002, Figueroa and Sanchez-Cordero 2008, Chhatre and Agrawal 2009, Bray 2010). Accordingly, striving for forest conservation while sustaining rural livelihoods is a recognized global challenge (Naughton-Treves et al. 2005).

Community forestry $(\mathrm{CF})$ is an evolving and promising approach to forest management, shown to be effective in not only maintaining forest cover and conserving biodiversity, but also generating income for local communities (Bray et al. 2004, Bray et 
al. 2008, Ellis and Porter-Bolland 2008, Porter-Bolland et al. 2012). In a CF approach, communities actively participate in or directly control the management process, integrating their culture, traditions, and values within the main goal of sustainable livelihoods and natural resource conservation, where generating employment is more important than profit (Asbjornsen and Ashton 2002, Antinori and Bray 2005). Community forestry can cover a variety of management techniques, from management for strict protection, to non-timber forest products (NTFPs) for subsistence or markets, to management for the commercial production of timber. Mexico is the leading example in the world in community-based management of forests for commercial timber production (Bray et al. 2003).

There is a synergistic relationship between forest health and livelihood benefits, especially when recognition of forest resource rights is part of decision-making and policies. Studies have shown that, when given the authority and recognition of their customary or formal rights over forests, communities will limit their extractions of forest products and apply sustainable approaches to their management practices, thereby maintaining biodiversity and forest cover while enhancing carbon stocks (Bray et al. 2003, Chhatre and Agrawal 2009, Bray 2010, Porter-Bolland et al. 2012, Stevens et al. 2014, Baraloto et al. 2014).

With increasing recognition of community land rights and devolution of control over what can become common-pool forest resources in various regions worldwide, community management and conservation have been an ever-growing means of forest protection in recent decades. Molnar et al. (2004) propose that there are four main types of community-driven conservation globally, defined by intensity of forest use, cultural 
relationship with the land, and the time the particular resource has been managed by human populations. The first type consists of landscapes that are intensively managed and where long-time settlers apply individual and community-based management and active restoration, but may or may not have legal rights over their land and resources. Intensively managed lands under active restoration and management are perhaps the most widespread type of community conservation, and are usually common in areas with high human population density (Molnar et al. 2004). Densely populated and intensively managed areas tend to be limited in their ability to support wild species that need large areas of contiguous forest habitat. However, with proper protection of crucial niches and adequate resource management techniques, ecological communities can be sustained (McNeely and Scherr 2003).

The second type comprises forest perimeter areas dominated by recent settlers involved in resource extraction, agriculture, and/or pastures, and who also may or may not have legal rights over resources. Here, large patches of natural habitat are found in and around farming areas. Management in these forests tends to follow the practice of low intensity use of remaining forest and practices of agroforestry, agriculture and/or cattle grazing that conserve ecosystem functions in the converted areas (Molnar et al. 2004).

The third type would be the conservation of large forested areas that are lightly used and have indigenous and traditional stewards, which can be considered equivalent to conservation in large public protected areas. In these forests, conservation combined with cultural continuity and self-development is the main goal. Such conservation promotes the maintenance of large non-fragmented areas that are able to sustain large species and 
natural habitats, as well as conservation of their territories for long-term livelihood development and cultural subsistence (Molnar et al. 2004). Indigenous-managed territories in the Brazilian Amazon, for instance, have been shown to not only conserve biodiversity, but also significantly reduce deforestation and control fires, as well as colonization within their borders (Neptad et al. 2006).

The fourth type of community conservation, and the most pertinent to this study, includes working forest landscapes owned and/or managed by communities, which encompass large patches of natural habitats suitable to biodiversity conservation, as well as areas under management for logging, agroforestry, agriculture, and/or grazing (Zarin et al. 2004). The study area for the present thesis, Sierra Norte of Oaxaca (SNO), fits into this category. These forests usually have intensively used spaces under established, adaptive management practices that are focused on a stewardship relationship with nature and the environment (Molnar et al. 2004). In many cases, as in SNO, communities set aside parts of the forest for more strict conservation, and others for complementary management of resources for multiple uses and purposes, including logging (BorriniFeyerabend 1997, Molnar et al. 2004). The current thesis will examine how forest cover maintenance and local livelihoods have been combined through land-use zoning and timber production, managed by indigenous communities in the Sierra Norte of Oaxaca, Mexico.

Mexico is among the five most biologically "mega-diverse" countries in the world, comprising 10-12\% of all known species (CBD 2013). The country is just as diverse culturally. According to the World Bank (2014), Mexico's population is at approximately 125.4 million inhabitants, with an estimated ten million indigenous 
peoples speaking 56 recognized indigenous languages (Fox n.d.). The International Institute for Sustainable Development estimates that about 13 million people are supported by goods and services provided by Mexican forests (IISD 2014). Therefore, forest conservation and sustainable management are an extremely important matter, from an ecological, as well as social point of view.

An estimated $60.3 \%$ of Mexico's forestlands are owned by communities with nearly full property rights (Madrid et al. 2009). Of communities with commercial sized forests, which can be as small as 200 hectares, it is projected that about 1,600 to 2,300 have logging permits - the number may vary substantially from year to year. These logging communities can be categorized as Community Forest Enterprises (CFEs), which means they produce timber under government-approved management plans and partake in varying degrees of vertically-integrated industrial activities, from producing logwood and sawnwood to finished wood products such as furniture (Bray et al. 2007, Molnar et al. 2011).

Mexican CFEs are one of the most sophisticated systems of community timberbased enterprises globally. It is estimated that, in southern Mexico alone, over 400 communities manage 7 million hectares of forested lands for timber and non-timber harvests (Molnar et al. 2004). The CFEs in Mexico have been successful in creating jobs and generating income for local community members in rural Mexico. The profits of CFEs are used to invest in community assets such as schools, potable-water networks and clinics, as well as profit distribution, while their management practices promote the expansion of forest cover, productivity, and conservation (Bray et al. 2003). 
In the state of Oaxaca, southern Mexico, communities govern $82.3 \%$ of their forests (Madrid et al. 2009), and have consistently rejected the idea of creating Biosphere Reserves or other Public Protected Areas that would limit their communal land rights (Bray 1991, Bray et al. 2012). The Sierra Norte region, in particular, showcases the benefits of community-governed, multifunctional landscapes regarding sustainable land use and forest conservation (Robson 2007, Robson and Berkes 2011). The forests of SNO were logged for some thirty years under industrial concessions, but since the early 1980s, they have been under the direct management of CFEs conducting significant logging and other natural resource activities, both extractive and non-extractive; yet, they continue to maintain high forest cover and biodiversity (Brandon 2005, Gomez-Mendonza et al. 2006).

In the remainder of this literature review, I will: 1) provide the context for how this unusual phenomenon emerged, focusing on common property in the Mexican context and the emergence of CFEs; 2) discuss community forest management (CFM) in relation to deforestation; 3) consider the contributions of CFM to global climate change mitigation; 4) present the different types of sivicultural systems applied in my study site, Sierra Norte of Oaxaca; 5) introduce the concepts of land sharing and land sparing; then finally 6) discuss community land-use zoning (LUZ) as practiced in SNO, and review "formal" and "informal" community conservation practices in the region.

In chapter 2, I will deliver the specifics of my research, expand upon my study area, describe the methods used, and discuss the results found. I will illustrate how the indigenous communities in Sierra Norte have been able to reconcile forest conservation, and apparently sustainable livelihoods through community land-use zoning and well- 
managed timber production, thus proving that it is possible to acquire forest goods and generate income for local communities, while conserving forests and maintaining ecosystem services.

\section{Common Property Regime and the Emergence of Mexican CFEs}

A Common Property Regime is a system of social organization that regulates the preservation, maintenance, and consumption of common pool resources (CPR). Ostrom (1990) defines CPRs as collectively managed resources that are large enough that exclusion of outsiders would be costly but not impossible, and that are subtractable, or rival, meaning that the use from one user limits the quantity available for others. In many parts of Mexico, defending and assuring those rights can be costly, however in SNO these costs are reduced because of generally clear property rights (Bray and Merino-Perez 2012). Community pool resources can include pastures, irrigation systems, fisheries, groundwater (Ostrom 1990), as well as forests (Agrawal et al. 2007).

Common pool resources are governed in a variety of ways with the central objective of promoting sustainable use to maintain benefits for all those who contribute to the management of the land and/or resource. Users of a common pool resource are predicted to engage in collective action around a CPR when the benefits, which may be economic or social, exceed the costs (Ostrom 1990). Collective action can also be facilitated by the existence of norms of cooperation, and sanctions for non-cooperation, frequently found in traditional communities such as those in SNO.

Mexico presents a unique case of common property regime in its land tenure system, with about $60.3 \%$ of the country's forestlands owned and managed by 
communities (Madrid 2009). There are two categories of this collective land regime: Ejidos and Comunidades. Ejidos refer to communal lands managed by farmers who may have originally been "landless laborers" (those who do not own or rent any land, and earn a living by working on someone else's land), and Comunidades (hereinafter denoted simply as "communities") refer to lands with titles dating to the Spanish colonial period, that are managed by communities of indigenous peoples (Bray et al. 2003, Barry et al. 2010). This distinctive structure came about as a result of the Mexican Revolution, which took place from 1910 to 1917 (Bray 2010).

The devolution of land rights to local communities was one of the main demands of the Mexican Revolution, and in the following decades, agrarian land rights were progressively given to communities through presidential decrees. These rights included territorial size, the number of rightsholders, and geographical boundary measurements (sometimes disputed between communities), which were determined by the Secretaria de Reforma Agraria Nacional (SRA) or National Agrarian Reform Secretariat. However, until a 1992 constitutional reform, communities did not, in practice, have "tree rights", or ownership rights to community timber (Bray et al. 2003, Bray 2010, Barry et al. 2010).

In the 1930s, the Agrarian Reform brought about a clear legal framework and a "universal governance template", which would eventually give communities autonomy in forest governance. The template involved the establishment of a general assembly of all legal community members, who elected two sets of community leaders for three year terms, the Comisariado de Bienes Comunales (Commission on Common Properties, CBC), composed of a President, Secretary and Treasurer, and a Consejo de Vigilancia 
(Oversight Council), formed by a president and two secretaries, who may either support or monitor the performance of the Comisariado.

The role of the Comisariado is to: 1) act on behalf of the assembly's decisions as well as conflict resolution and community finances, 2) incite the respect of wishes of rightsholders, 3) convoke the assembly according to the law, 4) communicate and aid management and use of lands managed as common property, and other duties conferred by the assembly (Ley Agraria, 1992). The president (generally referred to as Comisariado) is the main representative of the community, the one who meets with government officials, and the one who grants permission for outside parties to work in the communities. The role of the Consejo de Vigilancia are to: 1) provide oversight and monitoring to the activities of the Comisariado according to community statutes, 2) review financial accounts of the Comisariado and report their findings to the assembly, 3) convoke the assembly when not done by the Comisariado, and other duties specified by the assembly (Ley Agraria, 1992).

All decisions pertaining to anything that affects the community are discussed at the Asamblea General de Ejidatarios/Comuneros, or a General Assembly of Rightsholders. At these assemblies, the communities, together with the $\mathrm{CBC}$ and the Consejo de Vigilancia, make all the decisions regarding their common property and resources. Some of the topics discussed at the Asambleas include: 1) the creation and/or modification of communal statutes, 2) acceptance and exclusions of new rightsholders, 3) communication of information from community leaders to the public, 4) management of community finances and accounts, 5) votes on contracts with third parties, among other things (Ley Agraria, 1992). 


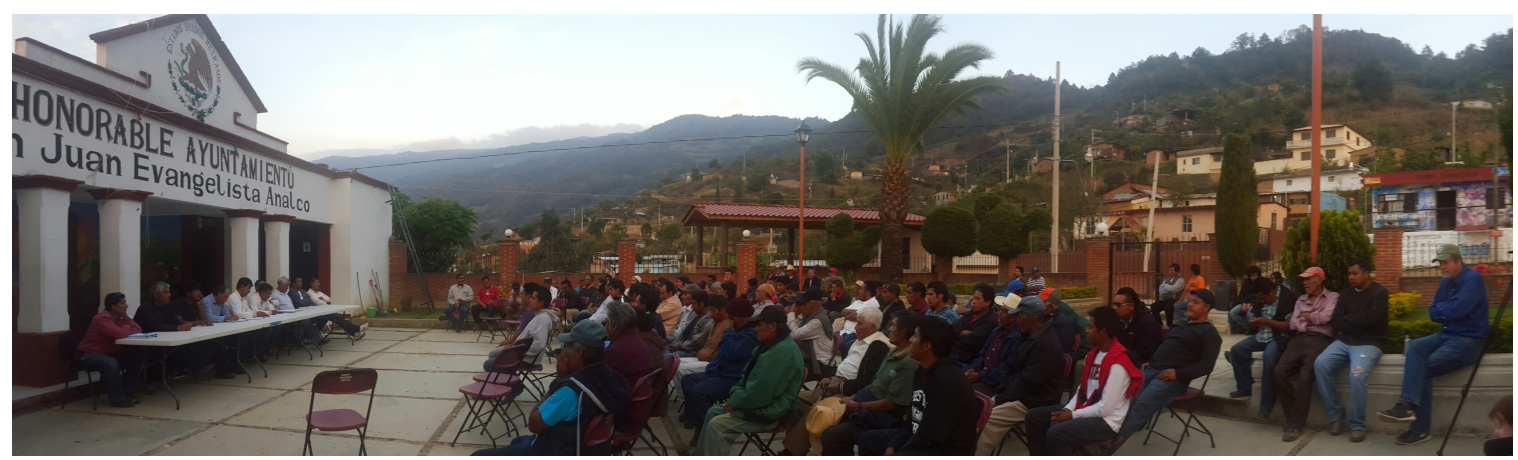

Figure 1: Asamblea General de Ejidatarios/Comuneros (General Assembly of Rightsholders).

The rise of Community Forest Enterprises began in the 1970s. During that time, Sierra Norte had been under a 25-year concession to a logging concessionaire, FAPATUX (Fabricas de Papel Tuxtepec), whose goal was to maximize logging of the forests for profits, without any sustainable management or reforestation. The malpractice perpetrated by FAPATUX caused significant degradation of the forests (Bray 1991). Given the situation, in the 1970s and 1980s, communities in Oaxaca, Durango, Quintana Roo and other states engaged in grassroots mobilizations to oppose the exploitation of their forests by private and public enterprises, such as FAPATUX, without the participation or agreement of the indigenous and rural communities. These efforts were supported by reform-oriented bureaucrats in the Forestry Under-Secretary and by 1983 in the SNO. After years of struggle, parastatal timber concessions were cancelled by the federal government, giving communities new management rights over logging in their forests (Bray 1991, Bray 2010).

In 1986, a new forest law was passed, which consolidated some of these management rights. The 1992 reform to Article 27 of the Mexican constitution finally transferred nearly all rights over the forests, except communities cannot sell land, or log without government permission (Fonseca 2005, Bray et al. 2005, Bray et al. 2007). Table 
1 shows a summary of 100 years of evolution of the community forestry sector in Mexico. It depicts the most notable events that occurred since the beginning of the Mexican Revolution in 1910, until 2010, by which time community forest management had started to get more support from the Government, which has since continued to expand.

Table 1: History of Mexican Community Forestry

\begin{tabular}{|c|c|c|}
\hline Year & Event & Remarks \\
\hline $1910-1917$ & Mexican Revolution & $\begin{array}{l}\text { Inspired by the abandonment } \\
\text { of small-scale farmers }\end{array}$ \\
\hline 1920-1992 & $\begin{array}{l}\text { Redistribution of forestlands } \\
\text { (state and private) }\end{array}$ & $\begin{array}{l}\text { Varying levels overtime, } \\
\text { mainly from 1934-1940 and } \\
1958-1976\end{array}$ \\
\hline Early 1970 s & $\begin{array}{l}\text { Beginning of government } \\
\text { efforts to decentralize control } \\
\text { over logging activities to local } \\
\text { communities }\end{array}$ & $\begin{array}{l}\text { Mostly in Chihuahua and } \\
\text { Durango }\end{array}$ \\
\hline $1976-1986$ & $\begin{array}{l}\text { First efforts to create } \\
\text { community forest enterprises } \\
\text { (CFEs) }\end{array}$ & $\begin{array}{l}\text { In Guerrero, Quintana Roo, } \\
\text { Oaxaca, and other areas }\end{array}$ \\
\hline 1986 & New Forest Law & $\begin{array}{l}\text { Gave communities new } \\
\text { authority over logging in their } \\
\text { forests }\end{array}$ \\
\hline 1992 & $\begin{array}{l}\text { Reform of Article } 27 \text { of } \\
\text { Mexican Constitution }\end{array}$ & $\begin{array}{l}\text { Ended state claims to } \\
\text { community timber, all } \\
\text { ownership rights given to } \\
\text { forests }\end{array}$ \\
\hline $1994-2010$ & $\begin{array}{l}\text { New government programs } \\
\text { and expanded budgets for } \\
\text { community forestry }(\mathrm{CF})\end{array}$ & $\begin{array}{l}\text { Renewed attention by Govt. } \\
\text { to } \mathrm{CF} \text {, and increased budgets } \\
\text { by hundreds of percent } \\
\text { (including for reforestation } \\
\text { and conservation) }\end{array}$ \\
\hline
\end{tabular}

Table 1: History of Mexican Community Forestry from 1910 to 2010 (highlights). Adapted from Bray 2010. 
The federal government has primary jurisdiction in regulating forest resources; SEMARNAT (Secretaría del Medio Ambiente y Recursos Naturales/Secretariat of Environment and Natural Resources) is the agency that regulates forest product extraction. In the 1990s, with the creation of the agency and the implementation of programs such as PROFEPA (Procuraduría Federal de Protección al Ambiente/Federal Attorney General for Environmental Protection), which prosecutes forest law violations; PRODEFOR (Programa de Desarrollo Forestal/Forestry Development Program); and PROCYMAF (Proyecto de Conservación y Manejo Sustentable de Recursos Forestales en México/Conservation and Sustainable Forest Management Project), a new institutional incentive was given to community forestry in Mexico. PROCYMAF, in particular, increased communities' social capital, diversifying forest management into areas such as water bottling and ecotourism, and developing organizational processes through participation forums.

In 2001, during the presidency of Vicente Fox (2000-2006), forest development programs (as opposed to regulation) were taken out of SEMARNAT and placed in the newly created and autonomous Comission Nacional Forestal or National Forestry Commission (CONAFOR). Both PRODEFOR and PROCYMAF then became programs of CONAFOR (Fonseca 2005, Bray et al. 2005). The Comission Nacional Forestal is a high level Commission that operates autonomously from SEMARNAT and reports directly to the president. The Commission is responsible for promoting forest sector development and preservation of the country's forests (Bray et al. 2005).

Over 100 communities and ejidos in Mexico have gotten their forests certified under the Forest Stewardship Council (FSC), verifying their sustainable management 
practices (FSC 2016). Mexico is unique in terms of the magnitude of community enterprises for commercial production of timber on the basis of a common property regime. The approach allows for the self-governance of territories that promote the preservation, maintenance, and sustainable consumption of a common pool resource, in this case, their forests (Bray et al. 2003). The apparent success of community forest management and CFEs in Mexico demonstrates that, when forests are well-managed, increased timber production can take place in more concentrated, designated areas (this will be further discussed), thus helping impede deforestation and forest degradation (Nepstad et al. 2004).

\section{Deforestation in Mexico and Community Forestry}

There are about 64.8 million hectares of forested area in Mexico, which cover $33 \%$ of the country's total territory (FAO 2010a). It is estimated that about 5.5 million hectares were lost between 1990 and 2010. There are many causes of deforestation. According to the REDD+ (Reducing Emissions from Deforestation and Forest Degradation) Readiness Plan, the major drivers in Mexico are land conversion for agriculture and livestock, illegal logging, forest fires, and diseases (CONAFOR 2014). Other drivers of deforestation include tourism, mining, and urban expansion (SEMARNAT 2009).

However, Mexico's Forest Resource Assessment (FAO 2010b) suggests that the rate of deforestation has declined by 53 percent from 2000 to 2010. Moreover, the REDD + Plan produced by CONAFOR shows data for declining deforestation since the late 1990s, with virtually no net deforestation in temperate forests - from an average of 
107,608 hectares per year from 1993 to 2002, to about 9,128 hectares per year from 2002 to 2007; which includes an expansion of 928 hectares in coniferous forests (CONAFOR 2010). A less recognized public program that has very likely contributed to reduced deforestation is the promotion of community land-use zoning (Ordenamientos Territoriales Comunitarios, OTCs), which will be discussed later. The OTCs define village areas, agricultural areas, and a variety of forest management and conservation areas.

Forest extraction activities may often be inevitable, especially in poor, rural areas (Hedge et al. 1996, Vedeld et al. 2007, Angelsen et al. 2014, Howlader et al. 2016). As such, the implementation of sustainable practices is imperative. Logging in many developing countries has resulted in increased forest degradation due to unsustainable practices, and subsequent activities such as colonists entering logging roads postextraction, which may add to deforestation activities with conversion of the land for agriculture (Laurance et al. 2009). Community forests around the world, under the right conditions, are often better regulated and protected, and their management tactics and policies are helpful in reducing deforestation and degradation, as well as illegal logging pressures (Honey-Rosés 2009, Butler 2011, Del Gatto 2013, Lambrick et al. 2014).

A recent report from the World Resources Institute (2014) that reviewed global literature stated that, among other findings: 1) deforestation rates are lower in community forests than in forests managed by other entities, 2) local communities and indigenous peoples are usually better guardians of forests than companies, large-scale farmers, and even government agencies, as some frequently regard forests as sacred, and 3) communities have a personal interest in managing their forests sustainably, as they rely 
on them for food, medicine, building supplies, and other services, for both current and future generations.

The consistently declining rates of deforestation in temperate forests of Mexico can be significantly attributed to the sustainable management of the country's forests practiced at the community-level - well over half of these lands are owned and managed by local (rural or indigenous) communities. In well-managed CFEs, degraded forestlands

are restored, and new trees are either naturally regenerated or planted, enhancing opportunities for restoration of forest cover. In addition, forest stands are managed for a variety of tree species and ages, thus maintaining ecological complexity. Furthermore, community forestry provides economic incentives for local communities to conserve their forests, and, by ensuring active management, it can also help reduce the impacts of pests and forest fires, which are also drivers of deforestation and degradation in Mexico, and can cause significant greenhouse gas emissions, enhancing global climate change (De Jong et al. 2004, Barry et al. 2010).

\section{Community Forest Management and Climate Change}

In Mexico, the role of forest management and conservation in contributing to climate change mitigation is highly recognized by the Government (SEMARNAT 2009). The proposed United Nations program to reduce deforestation and degradation, REDD+, suggests that these goals can be met through conservation, sustainable management of forests and the enhancement of forest carbon stocks. In addition, incentives like Payments for Ecosystem Services (PES) have been developed to reduce deforestation and restore forest ecosystems. Mexico has been a global leader in implementing PES programs 
through the Pago por Servicios Ambientales Hidrológicos or Payment for Hydrological Environmental Services (PSAH), and the ProArbol ("ProTree") Programs, both of which promote actions for the conservation, restoration and sustainable use of forests (CONAFOR 2014, Alix-Garcia et al. 2014).

ProArbol provides the country with an overarching framework for PES and integrates a number of other forest programs, such as the Programa Nacional de Reforestacion (National Reforestation Program, PRONARE), the Programa de Desarollo Forestal Comunitario (Program for Sustainable Community Forestry, PROCYMAF), and Programa para el Desarrollo de Plantaciones Forestales Comerciales (Program for the Development of Commercial Forest Plantations, PRODEPLAN). A total of 5,085 projects under the PES Programs are reportedly designated by CONAFOR, covering over 3 million hectares of forested area (SEMARNAT, n.d.).

Forest loss in Mexico causes the release of about 89 megatons of $\mathrm{CO}_{2}$ annually (FAO 2010b). However, deforestation is largely concentrated in tropical humid and dry forests (the current study focuses on temperate forests). As previously noted, there is a synergistic relationship between livelihood benefits, forest conservation, and carbon storage (Asbjornsen and Ashton 2002, Chhatre and Agrawal, 2009, Stevens et al. 2014). Thus, upholding the land and resource rights of inclusive communities, whose well-being is closely associated to their forests, is a crucial opportunity to fight climate change.

A number of supporting arguments advocating for CFM as an efficient approach to climate change mitigation has been recognized (Stevens et al. 2014). The World Resources Institute (2014) estimates that about 37.7 billion tonnes of carbon are stored in the living biomass of the 513 million hectares of government-recognized community 
forests, which account for $1 / 8$ of the forests in the world, and are equivalent to the carbon in all of North America's forests (FAO 2010). Were this carbon to be released into the atmosphere as $\mathrm{CO}_{2}$, it would equal to approximately 29 times the annual $\mathrm{CO}_{2}$ emissions of all passenger vehicles in the world (Stevens et al. 2014).

A recent study (Walker et al. 2014) showed that indigenous territories in the Amazon, which occupy about $30 \%$ of the land, store nearly one third $(32.8 \%)$ of all aboveground carbon in the region. Indigenous communities in Brazil, Colombia, and Peru have created what are called "Indigenous Life Plans", which identify and map harvest areas, as well as protected forested areas, and sacred and historical sites (Pollen et al. 2015). Some of these communities have been working on their Life Plans since the 1990s, and through them, have created well-organized governance structures that have achieved many of the objectives aspired by REDD+. These objectives include restoring degraded habitats for endangered species, creating livelihoods built on sustainable harvest practices, and managing forests in ways that have proven to promote ecosystem resilience and conservation (Pollen et al. 2015). Communities that have Life Plans make a very strong case for why these Plans should be considered as foundations for REDD+ activities, as their objectives are so closely aligned. This practice is similar to one commonly exercised in Mexico, and especially in Oaxaca and Sierra Norte: Land-Use Zoning (LUZ) plans.

As in the Amazonian indigenous territories and other communities with Life Plans, CFEs in Oaxaca have been shown to play a large role in helping mitigate climate change. Through land-use zoning and sustainable timber production practices, forest communities have actively been maintaining forest cover and decreasing degradation, 
thus reducing greenhouse gas emissions and enhancing forest carbon stocks (Bray et al. 2007, Chhatre and Agrawal 2009, Bray 2010, Bray and Duran-Medina 2014, Stevens et al. 2014). A forest that is sustainably managed, as the CFEs in Sierra Norte, can capture carbon while it is growing, store carbon in long-lasting wood products, and after harvest, new trees grow or are planted to replace those harvested. Over time, the carbon sequestered by forests under this management cycle of sustainable harvest, storage and regeneration/replacement can be greater than that of unmanaged forests, which tend to ultimately stabilize (Bray et al. 2007, Barry et al. 2010).

It has been proposed that the Sierra Norte of Oaxaca in particular, should be considered a "post-REDD+" landscape. With REDD+, developing countries are rewarded financially for reductions of carbon emissions resulting from conversion of forests to other land uses through international carbon markets. Community forestry, as exemplified by Sierra Norte and the above-mentioned communities with Life Plans, has been proposed as an alternative route to the goals of REDD+, as it does not require the complicated regulatory framework of carbon markets (Bray 2010).

\section{Silvicultural Systems and Forest Conservation in Sierra Norte}

\subsection{Silvicultural Practices}

The establishment of strict protected areas such as National Parks in pristine forests is the priority conservation tool in the tropics, and will likely remain as such (Gibson et al. 2011, Putz et al. 2012a). However, since extraction activities may be inevitable in rural forested areas in developing countries (Hedge et al. 1996, Vedeld et al. 2007, Angelsen et al. 2014, Howlader et al. 2016), it is important to implement management approaches that reduce negative impacts on biodiversity and forest health. 
In the case of timber extraction, it is essential to distinguish exploitative extraction, and responsible forest management and sustainable logging. In the SNO forest communities, various logging techniques are applied, including selective logging and selection cuts, as well as small clear-cuts.

Selection cutting is a practice where trees are harvested in a way that generates an uneven-aged forest structure. It can be done in a single tree or a group selection system. As the terms suggest, single tree selections remove individual trees of different sizes throughout the stand in a relatively uniform manner to preserve an uneven-aged stand; while group selection systems remove clumps of even-aged trees throughout the stand Zielke et al. 1999). Both techniques remove mature trees, leaving openings and young trees to grow, thus creating growing space for regeneration (Zielke et al. 1999, FFS 2010). Some advantages of selection cutting include lower potential for erosion, stands are usually more biologically diverse, and seeds come from residual stands, so there is certain ease of natural regeneration for some species (Zielke et al. 1999, FSS 2010). Disadvantages include difficulty in the establishment of some species (e.g. pine species, which need open spaces), and potential for more root competition in the residual stand Zielke et al. 1999, FSS 2010).

Selective logging is not the same as selection cutting. Selective logging is the practice of removing a small number of trees (usually the highest grade of timber, or most merchantable stems) and leaving the rest intact. It is often considered to be a responsible forest management practice that can maintain significant biodiversity levels after logging (Putz et al. 2012a). Managed selective logging is an example of Reduced Impact Logging (RIL), which is a carefully planned and controlled practice where only the trees needed 
for commercial use are felled during extraction activities, thus minimizing adverse impacts of logging (Putz et al. 2008).

Some forms of selective logging have, however, been found to have negative impacts on forests as well. It has been argued that selective logging is a major source of rainforest degradation in the tropics (Asner et al. 2009), and a contributor to the 400 million hectares of tropical forest that have been lost to timber production (Blaser et al. 2011). A study done by Stanford University in 2005 found unregulated selective logging to cause widespread destruction in the Brazilian Amazon, with 4,600 to 8,000 square miles of forest affected every year across five Brazilian states (Shwartz 2005).

Clear-cutting is another controversial logging technique that is widely practiced in forests managed for timber production around the world. Clear-cutting logging is a practice in which most or all trees are cut down. There are many negative impacts associated with this approach, which include: loss of habitat, since many animals that depended on the trees may be displaced; enhanced greenhouse gas emission, as a result of the large number of trees cut down; erosion, and soil damage, as trees act as anchors for soil, which when removed, may leave soil more susceptible to erosion (Keenan et al. 1993, WWF 2016).

Logging under any silvicultural regime may be associated with deforestation and forest degradation. However, silviculture as practiced in Sierra Norte shows that selective logging, selection cutting, and timber extraction in small clear-cuts can all be done in a biodiversity-friendly manner, when carried out in a matrix of community-protected forests (Bray and Duran 2014). 
One of the most common methods in Sierra Norte is the Mexican Method of Regulating Irregular Forests (MMOBI, Método Mexicano de Ordenacion de Bosques Irregulares). The MMOBI method is a selection method for uneven-aged stands, or stands containing trees of various age classes, height, and diameter. Such uneven-aged system allows for more predictable growth over the long term. Regeneration cuttings are done throughout the rotation, which facilitates uneven-aged management, promoting perpetual restoration (Zielke et al. 1999). The MMOBI method is considered to be an environmentally friendly extraction technique, since it maintains a continuous canopy as well as the natural structure of the forest. However, the practice does not contribute to the regeneration of pine, the most important commercial species, since it is a heliophytic species that requires large sun-lit gaps to establish (Bray and Duran-Medina 2014).

The second main silvicultural practice in Sierra Norte's forests is the Silvicultural Development Method (MDS, Método de Desarrollo Silvícola), which was introduced to address some of the deficiencies of MMOBI for pine management. The goal of MDS is to fully capture the productive potential of the forest, through the use of techniques appropriate for the different forest conditions. A harvest plan is scheduled to obtain equal volumes and distribution of products and establish stands of even-aged trees. The MDS method is characterized by a series of cuts or a logging cycle which can include: a) prethinning, often performed to control the composition and density of the forest, and uniform distribution or pattern spacing; b) thinning, which generally takes out trees that are deformed, diseased and/or deemed noncommercial trees; c) regeneration, which takes out most of the trees in the cutting area, leaving a selection of mature trees that have good 
seed production capacity; and d) liberation, done when standing trees are felled to eliminate competition with the ones in regeneration (Bray and Duran-Medina 2014).

In addition to MMOBI and MDS, three other silvicultural methods are applied in Sierra Norte: the Conservation and Silvicultural Development System (SICODESI, Sistema de Conservacion y Desarrollo Silvícola), "group selections" or "strip clear-cuts", and Restoration Logging. The SICODESI method is similar to MDS in some aspects, but it includes socio-economic, technological, and environmental impact studies as a basis for planning forest harvests (Hernandez-Diaz et al. 2008). Group selections or strip clearcuts refer to the extraction of all tress of all diameters in blocks of .25 to .75 hectares. And Restoration Logging is a method focused on the restoration of highly degraded forests, such as those affected by forest fires (Bray and Duran-Medina 2014).

As it can be seen, logging communities in SNO have a variety of silvicultural practices, representing varying degrees of logging intensity, in designated forest management areas. All of these practices are applied within the concepts of land-use zoning, which will be discussed in subsequent sections.

\subsection{Land Sharing vs. Land Sparing}

In order to combine natural resource extraction with biodiversity conservation, two general strategies can be implemented: the resource may be harvested at low intensity across a whole area, causing low levels of disturbance at any given point on the overall region; or alternatively, it could be harvested at higher intensity within a specific zone, leaving the remaining area untouched. These strategies convey the concept of land 
sharing vs. land sparing, a debate often present in land use management in agricultural and forest landscapes (Phalan et al. 2011, Edwards et al. 2014).

Studies have been done to address the many challenges of biodiversity conservation and production of human commodities, such as food and timber. Phalan et al. (2011) conducted a study comparing crop yields and densities of bird and tree species across areas of low and high intensity agriculture in southwest Ghana and northern India. The study found that in both countries, most species from both taxa had higher population under the land sparing approach, which minimized the negative effects of food production on biodiversity.

Edwards et al. (2014) compared abundances and species richness of birds, dung beetles, and ants in Borneo, between concession areas that represented lower intensity logging across the site (yields of about $113 \mathrm{~m}^{3}$ of timber per hectare; land sharing), and high intensity zoned logging (twice logged areas with yields of $113 \mathrm{~m}^{3}$ of timber per hectare; land sparing). The authors found that within all three taxa, both abundance and richness were higher in the areas where land sparing was applied.

Land sharing logging integrates low impact timber extraction with biodiversity and forest protection on the same extensive area, whereas the land sparing approach minimizes the region to be disturbed by maximizing yield in one particular zone, thus emphasizing more intensive production (Edwards et al. 2014). Logging and, generally, agriculture in Sierra Norte take place in concentrated areas, with significant additional forest being either in reserve for future extractive activity or in permanent protection under community land-use zoning practices - i.e., OTCs (land-use zoning plans) and PMFs (forest management plans). The OTCs informally, and PMFs more officially, set 
up a written framework of land sparing, with clearly zoned agricultural and forest areas. Accordingly, land-use zoning (LUZ) practices carry out both a land sparing approach in zoning agriculture and forests, in addition to a forest sparing logging approach by zoning the forest areas. These LUZ practices will be discussed in the next section, then further explored in Chapter 2.

\subsection{Land-Use Zoning Practices and Forest Conservation in Sierra Norte}

The zoning of the community territory into broad urban, agricultural and forest uses sets the overall framework for a large variety of classifications of land use. There are two forms of community land-use zoning, one of which is formal as part of the SEMARNAT-approved Programas de Manejo Forestal (Forest Management Plans, PMFs), and the second, which is informal, although commonly supported in their elaboration, is the Ordenamientos Territoriales Comunitários, or Land Zoning Plans (OTCs).

The PMFs are documents created by SEMARNAT in accordance with Mexican laws to set the guidelines, criteria and specifications for extraction of timber resources in forests, jungles and zones of arid vegetation (SEMARNAT 2008). The main objectives of PMFs are to implement activities of general land use, production, conservation, restoration and forest protection, to reverse occurrences that negatively affect the ecosystem, and to establish better conditions for regeneration and growth of forest mass, in order to ensure its stability and functionality (SEMARNAT 2015).

These management plans are usually implemented for periods of 10 years, in regulatory terms established by the General Law on Sustainable Forestry Development 
(Ley General del Desarrollo Forestal Sustentable de México, LGDFS). Thus, PMFs have the force of regulatory law in their designation of the uses of the forest, and are therefore "formal", although these Plans do have to be approved by the community before they are presented to SEMARNAT. The PMFs designate the specific areas to be logged; the harvest cycles, which can be from 40 to 60 years; silvicultural systems used and complementary silvicultural treatments; authorized volumes of timber for the ten-year plan; and other practices pertaining to forest production and conservation. In many cases, PMFs are elaborated following the appraisals and land zoning of OTCs.

The OTCs are participatory appraisals of communal land uses and created by a committee of community members and authorities, usually facilitated by a nongovernmental organization (NGO). These documents aim to combine the goals of conservation and indigenous communities' territorial and social rights (Perez et al. 2006, Chapela and Lara 2007). They were first proposed and implemented by the Oaxaca nongovernmental organization Estudios Rurales y Asesoria (ERA) and were later picked up as a major program and policy instrument by CONAFOR.

The establishment of OTCs has had a notable impact on community forests in Mexico. According to Fonseca (2006), they have strengthened the communal institutions (such as CFEs), through clear agreements between the local people, which give communities a greater sense of identity and recognition of their common purposes. Through a "shared vision", it allows communities to define common strategies for longterm use of their resources and leads to greater ownership of their forests. The development of OTCs also ensures that any member of the community can express his or 
her needs and concerns about the rights and limitations on the use of resources (Anta Fonseca 2006).

Following consolidation of the land uses in the OTCs, many communities formalize and register the rules as estatutos comunales, or communal statutes (internal regulations), with the National Agrarian Registry. Implementation of the statutes enforces that the rules and regulations regarding the use, access, and conservation of communal lands, and regarding rights and obligations of all community members, should be followed and respected. In many cases, these communal statutes are the main regulatory instruments used by the general assemblies to monitor and sanction community members (Anta Fonseca 2006).

Because of the variability of land use in SNO's community forests, it is understandable that communities have consistently opted out of the creation of Biosphere Reserves or other public protected areas that would take away from their communal lands and rights, and consequently be more binding and restrictive. There are no public protected areas in SNO; on two separate occasions, where the Government attempted to push for the creation of Reserves, communities democratically voted against it (Bray 1991, Bray et al. 2012).

Conservation areas in SNO communities can be classified as either "formal" or "informal". Formal conservation in this case, given the absence of protected areas, is expressed through a) the PSAH programs, and b) the "certification" of conserved areas on community lands (VCAs). In contrast, "informally" conserved areas are only established and recognized at the community level. They are defined in the PMFs and OTCs, even though this does not give them any official status as protected areas. 
The OTCs and PMFs are the major vehicles for the informal recognition of community-conserved areas. Through the elaboration of these documents, and without seeking government recognition, communities set aside areas to be protected, and create rules against agricultural expansion into primary forests, thus helping to preserve biodiversity (Chapela and Lara 2007). Informally protected areas in SNO communities include areas for the protection of habitats for threatened or endangered species, watershed protection, recreational areas, protection of cloud forests, soil conservation, areas for natural regeneration, reforestation and restoration areas, and areas of high biodiversity value. This informal conservation defined by OTCs and PMFs is the most common manner of community-conservation across all CFEs in Sierra Norte.

Conversely, there are two types of formal community conservation: 1) areas under payment for hydrological environmental services (PSAH), and 2) areas for protection under voluntary certification programs (Voluntary Conserved Areas, VCAs). For these types of formal conservation, communities collaborate with government agencies like CONAFOR and the National Commission of Natural Protected Areas (CONANP) to obtain financial support in the form of payments for ecosystem services (PES) such as PSAH, and certifications for their well-managed forests.

Historically, formal protected areas were declared over communities (Calakmul Biosphere Reserve, for example), denying resource rights over what were still legally communal lands. However, after a 1997 amendment to the environmental law, the presidential decree of protected areas now legally requires community consultations. A new mechanism for establishing a form of protected area was created in 2008: Voluntary Conserved Areas (VCAs). As the name suggests, VCAs are voluntary programs that 
communities opt to apply for. The certification is recognized under CONANP, although these areas are managed by the communities themselves (Alix-Garcia et al. 2014, LGEEPA 2008).

The VCAs are an example of Indigenous and Community Conserved Areas (ICCAs). The IUCN (International Union for Conservation of Nature) defines ICCAs as "natural and/or modified ecosystems including significant biodiversity values, ecological benefits and cultural values voluntarily conserved by indigenous and local communities, both sedentary and mobile, through customary laws and other effective means" (BorriniFeyerabend et al. 2002, IUCN/CEESP 2008). They are locally declared protected areas that can be grouped in five categories: protected communal areas, forestry management protected areas, sacred natural sites (SNSs), and wildlife management areas; in addition to the certified community reserves (Martin et al. 2011).

Pago por Servicios Ambientales Hidrologicos (PSAH) is a PES program that works under five-year contracts and promotes actions for the conservation, restoration and sustainable use of forests. Between 2003 and 2011, CONAFOR supported communities with approximately $\$ 450$ million, and enlisted more than 2.6 million hectares of land in the program (CONAFOR 2014, Alix-Garcia et al. 2014).

As opposed to advocating for the establishment of inevitably more restricted Protected Areas, community forests in Oaxaca and in Mexico have proven to be an important contributing element in the maintenance of forest cover and conservation of biodiversity, and consequently, climate change mitigation. Van Vleet et al. (2016) conducted a study in a 7-community region of Sierra Norte and found that the communities in the area had an average of $88.3 \%$ forest cover, attributed mainly to 
informal conservation based on land-use zoning and community rules. The authors note that a degree of conservation can also, however, be dedicated to remoteness, low population, and steep slopes. Nonetheless, they suggest communities in Sierra Norte are a good example of strong organizational process around sustainable forest management and conservation.

Through community land-use zoning and well-managed silvicultural practices put forth at the community-level, the CFEs in Sierra Norte showcase that the balance between human survival needs and conservation is possible. In chapter 2, based on this argument, I will frame data collected during 11 weeks of field research in Oaxaca around the concepts of land-use zoning, as well as land sharing/sparing, in the context of community management and conservation. I will document the magnitude of land use and the degree of almost exclusive informal forest conservation in SNO. In addition, I will quantify the flow of forest goods (i.e., timber) being produced under management plans in these community forests for periods of 10 to 20 years (1993-2003 and 20032013). Finally, I will assess the contributions of community forest management for timber production and strict protection as an instrument of forest conservation in Sierra Norte. 


\section{CHAPTER 2: Logging and Community Conservation in Sierra Norte}

\section{Introduction}

\subsection{Background}

A growing global population has continuously increased the demand for goods and services provided by forests. As a result, efforts to achieve conservation while supporting livelihoods, particularly in developing countries, have become paramount to the preservation of our natural resources. Trade in timber products, for instance, has increased significantly over the last 50 years (WWF 2016); according to FAO (2010), wood-based trade has gone up 800 percent in the past three decades. Reconciling this demand with biodiversity and forest conservation, and assuring benefits to local and indigenous communities is a recognized challenge.

A debate over how to address the challenge has arisen: the concept of land sharing/land sparing. The land sharing/land sparing concept first emerged to discuss whether intensive agricultural production in smaller areas, leaving larger forest areas under conservation, is a superior conservation strategy to having lower intensity agriculture scattered throughout the land (Phalan 2011). The same concept has been applied to forest management. Land sharing/land sparing logging evaluates whether it is better to promote intensified timber production in a concentrated area to reduce logging pressure on remaining forests (land sparing), or whether it is of greater benefit to integrate production and conservation in the same area, applying less intensive logging practices across the forest landscape (land sharing). In other words, what is the best way to achieve the greatest conservation outcomes, given the demands for timber production and local livelihoods? 
However, there are a number of questions to be asked: Who decides what land to share, and what land to spare? How exactly are these practices implemented? What kinds of policies are in place? The literature on the subject does not seem to address these questions. As well, land sharing/sparing within the context of community-based conservation and management specifically, has not been explored to date. I will use this analytical framework in the context of community governance and conservation in the Sierra Norte region of Oaxaca (SNO), Mexico. In SNO, through land-use zoning (LUZ) practices and well managed timber production, lands entirely owned by indigenous communities have been applying both a land sparing approach regarding land use, in zoning agricultural areas and forests, in addition to a forest sparing logging approach, regarding forest use in particular, by zoning areas for timber production and for conservation.

Land-use zoning in Sierra Norte can be carried out through two different mechanisms: 1) Forest Management Plans, which are legally required, and 2) OTCs, informal participatory exercises. Both zone the territory into four broad categories: 1) conservation areas, 2) production areas, 3) restoration areas, and 4) other uses (which include agricultural areas). Within the production areas, different levels of logging intensity can be observed, as evidenced by the practice of selection cuts, selective logging, and varying forms of small clear-cuts, applied separately or in combination in different communities.

The silvicultural practices applied in Sierra Norte follow two principal reproduction methods: one uneven-aged (MMOBI), and one even-aged (MDS). The MMOBI method is considered to be the more environmentally friendly extraction 
technique, since it exclusively uses selection cuts, thus maintaining a continuous canopy as well as the natural structure of the forest. However, this practice does not contribute to the regeneration of pine, the most important commercial species, since it is a heliophytic species that requires large sun-lit gaps to establish (Bray and Duran-Medina 2014). The MDS method was introduced to address some of the deficiencies of MMOBI for pine management. The goal of MDS is to fully capture the productive potential of the forest, through the use of techniques appropriate for the different forest conditions. A variant of the MDS practice is also applied in Sierra Norte; SICODESI, which includes both a long (Strategic Planning) and short-term (Operative) plan of management, while MDS only includes the short-term.

Generally, logging is a controversial activity because of the negative impacts it may have on the environment, such as deforestation, loss of habitat, and generating greenhouse gas emissions. However, if timber harvesting is planned and well managed, it can be beneficial to forests by controlling fires, encouraging new growth, and particularly, promoting resilience (Pace et al. 2015). Forest ecosystem resilience can be enhanced through management, governance, and integration of natural and human frameworks, starting with the establishment of goals and conscious management actions that sustain, restore, and buffer ecosystems and their services (Pace et al. 2015). Biggs et al. (2012) suggest that actions that maintain diversity, manage connectivity, and monitor responses of ecosystems to disturbances are some of the management practices that help enhance resilience. All of these practices can be seen in the active management of the community forests in Sierra Norte, where policies and management regarding rights to 
their territory and natural resources sustain cultural practices in ways that preserve ecological systems.

Prior to the 1980s, SNO forests were passively conserved, as a result of factors such as agricultural land abandonment, emigration, and steep slopes. However, as previously discussed, after heavy forest degradation caused by FAPATUX and other parastatal timber companies during the concession period in the 1970 s, a more active approach was implemented, and since the 1980s, forest management for timber under community control has been a major tool for forest conservation; community members recognize that conservation of their natural resources is in their best interests.

Community governance clearly plays a large role in forest conservation in SNO. Much of the forested area in the region is under informal conservation; there are no public (or private) Protected Areas in the communities of SNO. All conservation is done at the community level, through the establishment of OTCs, the implementation of PMFs, and in some cases, as expressed by comisariados during interviews, communal statutes. All rules and regulations regarding the use, access, and conservation of communal lands are established and enforced by community members.

Communities with commercial sized forests that have logging permits and management plans can be categorized as Community Forest Enterprises (CFEs), which means they produce commercial timber at various levels of vertical industrial integration, from producing logwood to the production of furniture. The CFEs in Mexico are among the most sophisticated systems of community timber-based enterprises globally, and they have been successful in creating jobs and thus generating income for local community members in rural Mexico. Mexican CFEs have also shown to play a large role in reducing 
deforestation and helping mitigate climate change. Studies show that in areas where CFEs are mature, deforestation rates are either low or forests are actually expanding (Bray 2010, Barry et al. 2010). The central region of Quintana Roo, an area that is dominated by community forests, has the lowest rate of deforestation in all of Southern Mexico, a region that includes few natural protected areas (Bray et al. 2004, Barry et al. 2010). Another study shows that the Sierra Norte region, has not only maintained forest cover, but has expanded its pine-oak forests by 3.3\% over a 20 -year period (GómezMendoza and Arriaga, 2007).

The different types of CFEs are categorized by CONAFOR according to their level of vertical industrial integration. "Type I" communities are those with forestry resources who do not currently have logging permits (also called "potential producers"); "Type II" communities sell standing timber "on the stump" to outside contractors, with varying degrees of community supervision; "Type III" communities produce logwood and have extraction equipment like skidders, tractors and trucks, that is delivered to sawmills and "Type IV" are harvesters and processors, who own sawmills or other processing facilities such as furniture factories (Anta Fonseca 2005).

For the remainder of the present thesis, I use the concept of land sparing in the context of community conservation and management to frame the analysis of data on 23 communities of SNO (two Type II, six Type III, and 15 Type IV). I analyze volumes of timber harvested in periods of 10-20 years (1993-2003 and 2003-2013). By evaluating land-use zoning practices, I document how communities in SNO have used LUZ exercises to practice land sparing in their land as a whole and forest sparing in their forests, as well as their degree of informal forest protection, thus illustrating the 
significance of land-use zoning in conservation. I will showcase how, in a region with no public protected areas, indigenous communities are conserving large expenses of forest through conservation zoning and careful management of logging areas, thus obtaining forest goods, while maintaining ecosystem services and promoting resilience.

\subsection{Research Questions and Hypotheses}

The overall questions I pursued in my research were:

1) To what degree are the forest communities of SNO conserving forests, while also carrying out timber production?

2) What percentages of the forests are being logged and what percentages are being conserved?

3) How much timber has been removed from the region in the last 10-20 years (1993 to 2003 and 2003 to 2013)?

4) What are the implications of silvicultural practices applied in SNO, for timber production and forest conservation?

5) What are the different forms of forest conservation practices in the communities?

Beyond these questions, my overall hypothesis was that the communities of Sierra Norte are reconciling timber extraction with forest conservation in a likely sustainable way, while contributing to forest-base livelihoods. I then developed some specific postulations about why some communities produced more timber or conserved more than others. Thus, prior to collecting data, I hypothesized that: 
1) There would be a relationship between typology and size of territory, size of production and conservation areas, and volumes of timber logged - Type IV communities would be the largest, with largest production areas and highest volumes of timber logged, since these communities have the highest level of vertical integration.

2) There would be a relationship between size of territory and forested areas, size of conservation and production areas, as well as volumes of timber logged The communities with the largest territories would have larger forested areas and largest relative areas under conservation and under production, in addition to logging the highest volumes of timber.

3) There would be a relationship between human population density and size of conservation and production areas, as well as volumes of timber logged - The communities with lower population densities would have larger areas under conservation and less under production.

4) The communities with low volumes logged, relative to volumes authorized, would have made the conscious decision to log less in order to conserve their forests.

\section{Methodology}

\subsection{Study Area and Community Selection}

There is substantial existing evidence that the state of Oaxaca, in southern Mexico, particularly the Sierra Norte area, showcases the positive outcomes of communitygoverned landscapes regarding sustainable land use and conservation (Robson 2007, Robson and Berkes 2011, Van Vleet et al 2016). For over three decades, the community 
forests in the Sierra Norte have been involved in significant logging and other natural resource extractive activities and yet, they continue to maintain high forest cover and biodiversity (Brandon 2005, Gomez-Mendonza et al. 2006).

The SNO has a variety of definitions as to its geographical extent. One of the most common is to use the official Oaxaca state government administrative divisions, which includes a neighboring area (the Mixe region) with a different land-use history. In this study, Sierra Norte of Oaxaca (SNO) is defined not by bureaucratic divisions, but by the contiguous forest mass of the Sierra Norte mountain range, which incorporates a few communities normally considered as part of the Central Valleys administrative region. The communities studied are temperate pine-oak forest communities with active Forest Management Plans (PMFs).

I started with a preliminary database created as part of a prior consultancy with The Nature Conservancy with 18 communities, as part of a REDD+ project. The database included information on a number of silvicultural and social variables, and timber volume data for ten years (2003-2013). The database was expanded to 30 Community Forest Enterprises that had been issued logging permits. However, I established that five of those communities were not executing their management plans (i.e., they were not logging at the moment, either because they were starting to implement or were in the process of renewing their plans). In addition, another two communities (San Juan Evangelista Analco and San Pablo Etla) were taken out of the database (Analco started logging in 2012, and Etla never implemented a logging plan), although they will be considered in the qualitative analysis. Consequently, the final database includes 23 communities, with 10 years of logging data for all of them, and 20 years of data for 12 of 
the communities. Table 2 shows a list of all 23 communities, the municipality where they are located, and their CONAFOR Typology. Figure 2 shows a map of Oaxaca and the municipalities that encompass the communities in the study.

Table 2: Sierra Norte Communities

\begin{tabular}{|c|c|c|c|}
\hline ID & $\begin{array}{c}\text { Name of } \\
\text { Community }\end{array}$ & Municipality & Type \\
\hline 1 & Santa Maria Nieves & San Juan Quiotepec & II \\
\hline 2 & San Juan Luvina & $\begin{array}{c}\text { San Pablo } \\
\text { Macuiltianguis }\end{array}$ & III \\
\hline 3 & $\begin{array}{c}\text { San Juan } \\
\text { Tepanzacoalco }\end{array}$ & San Pedro Yaneri & III \\
\hline 4 & Zona 2 El Carrizal & San Pedro Yolox & III \\
\hline 5 & $\begin{array}{c}\text { Pueblos } \\
\text { Mancomunados }\end{array}$ & $\begin{array}{c}\text { Sta. Catarina } \\
\text { Lachatao, Sta. } \\
\text { Maria Yavesia, y } \\
\text { Santiago Amatlan }\end{array}$ & IV \\
\hline 6 & $\begin{array}{c}\text { San Francisco La } \\
\text { Reforma }\end{array}$ & San Pedro Yolox & IV \\
\hline 7 & $\begin{array}{c}\text { San Juan Bautista } \\
\text { Atepec }\end{array}$ & $\begin{array}{c}\text { San Juan Bautista } \\
\text { Atepec }\end{array}$ & IV \\
\hline 8 & $\begin{array}{l}\text { San Martin } \\
\text { Buenavista }\end{array}$ & San Pedro Yolox & IV \\
\hline 9 & $\begin{array}{l}\text { San Mateo La } \\
\text { Reforma }\end{array}$ & San Pedro Yolox & IV \\
\hline 10 & $\begin{array}{c}\text { San Pablo } \\
\text { Macuiltianguis }\end{array}$ & $\begin{array}{c}\text { San Pablo } \\
\text { Macuiltianguis }\end{array}$ & IV \\
\hline 11 & $\begin{array}{l}\text { Santa Catarina } \\
\text { Ixtepeji }\end{array}$ & $\begin{array}{l}\text { Santa Catarina } \\
\text { Ixtepeji }\end{array}$ & IV \\
\hline
\end{tabular}




\begin{tabular}{|c|c|c|c|}
\hline $12 *$ & $\begin{array}{c}\text { Zona } 1 \text { San Isidro El } \\
\text { Carrizal }\end{array}$ & San Pedro Yolox & II \\
\hline $13^{*}$ & San Andres Yatuni & Santiago Xiacui & III \\
\hline $14^{*}$ & $\begin{array}{l}\text { San Juan Bautista } \\
\text { Jayacatlan }\end{array}$ & $\begin{array}{l}\text { San Juan Bautista } \\
\text { Jayacatlan }\end{array}$ & III \\
\hline $15^{*}$ & $\begin{array}{l}\text { Teococuilco de } \\
\text { Marcos Perez }\end{array}$ & $\begin{array}{l}\text { Teococuilco de } \\
\text { Marcos Perez }\end{array}$ & III \\
\hline $16^{*}$ & $\begin{array}{l}\text { Capulalpam de } \\
\text { Mendez }\end{array}$ & $\begin{array}{l}\text { Capulalpam de } \\
\text { Mendez }\end{array}$ & IV \\
\hline $17^{*}$ & Ixtlan de Juarez & Ixtlan de Juarez & IV \\
\hline $18^{*}$ & La Trinidad & Santiago Xiacui & IV \\
\hline $19 *$ & Nuevo Zoquiapam & Nuevo Zoquiapam & IV \\
\hline $20 *$ & $\begin{array}{l}\text { San Miguel } \\
\text { Aloapam }\end{array}$ & $\begin{array}{l}\text { San Miguel } \\
\text { Aloapam }\end{array}$ & IV \\
\hline $21 *$ & $\begin{array}{l}\text { Santa Maria } \\
\text { Jaltianguis }\end{array}$ & $\begin{array}{l}\text { Santa Maria } \\
\text { Jaltianguis }\end{array}$ & IV \\
\hline $22 *$ & $\begin{array}{c}\text { Santiago } \\
\text { Comaltepec }\end{array}$ & $\begin{array}{c}\text { Santiago } \\
\text { Comaltepec }\end{array}$ & IV \\
\hline $23 *$ & Santiago Xiacui & Santiago Xiacui & IV \\
\hline
\end{tabular}

Table 2: Sierra Norte communities included in sample frame - all have 10 years logging data (2003-2013).

* Communities with 20 years of logging data (1993-2013). 
Figure 2: Map of SNO Municipalities in the Study

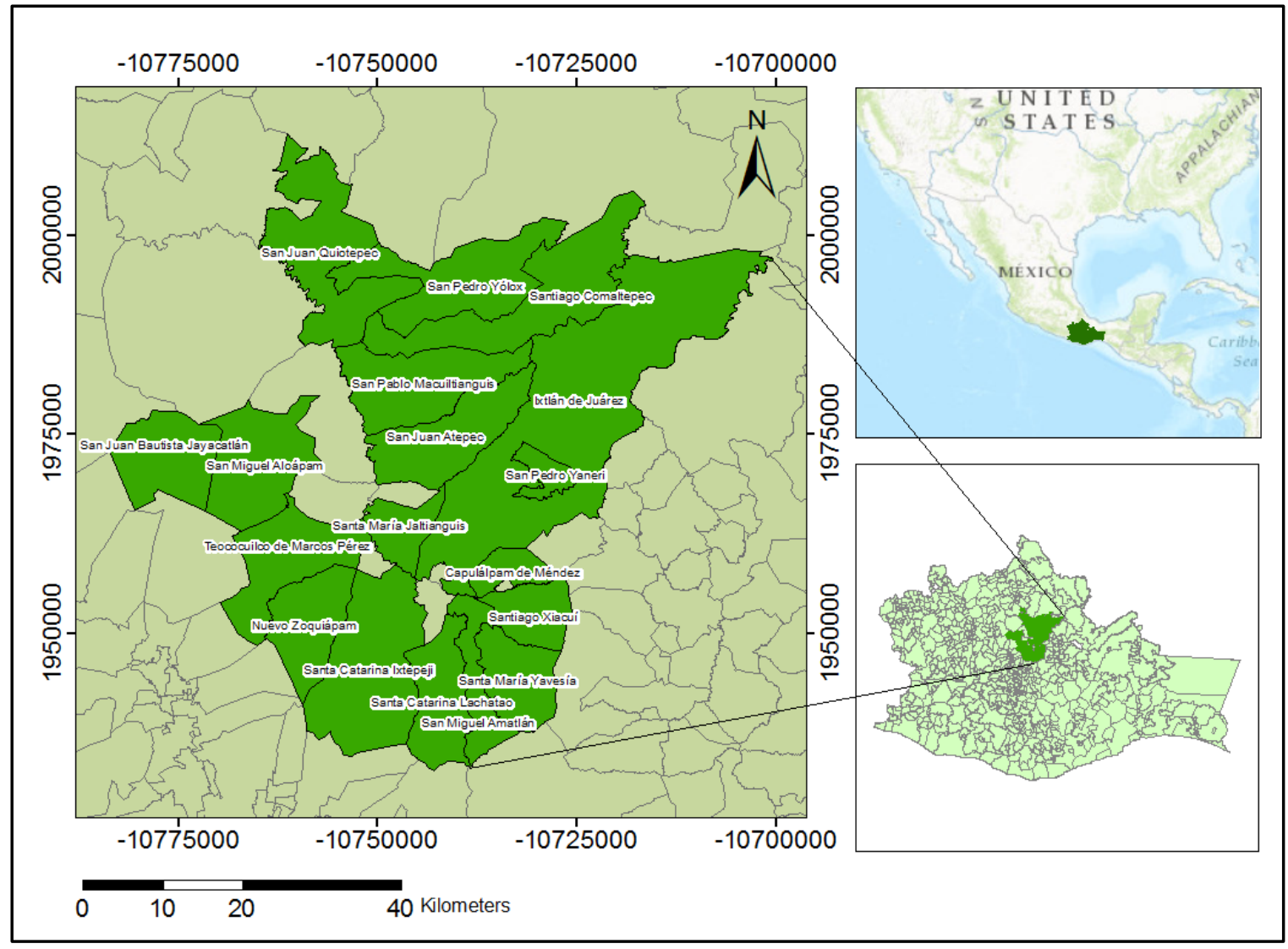

Figure 2: Maps of Mexico, Oaxaca, and the Sierra Norte municipalities in the study.

\subsection{Data Collection}

Data were collected in Oaxaca for a ten-week period in the summer of 2015 and ten-day period in March 2016. I used three different approaches: gaining access to the PMFs and OTCs; conducting semi-structured interviews with foresters responsible for the PMFs and a sample of community leaders; and community and forest visits.

\subsubsection{Archival research}

Archival research is a noteworthy method of collecting data because it is nonreactive and unbiased, as it relies on documents that reflect the time events occur, not a recollection of them (Ragin 2010). I used this method to acquire quantitative data 
accurately, which was done mainly from three sources: Forest Management Plans (Programas de Manejo Forestal, or PMFs), Land Zoning Plans (Ordenamientos Territoriales Comunitários, or OTCs), and Logging Annual Reports. The PMFs are reports required by SEMARNAT in accordance with Mexican laws to set the guidelines for extraction of timber resources (SEMARNAT 2008). OTCs are participatory appraisals of communal land uses, created by a committee of community members and authorities, foresters, etc. (Perez et al. 2006, Chapela and Lara 2007). Finally, Logging Annual Reports are documents that the responsible forester is required to submit to SEMARNAT each year, reporting the actual logged volumes, which may be less than the officially authorized volume.

As a consequence of the complexities of Mexican public access laws, it was not possible to get access to the PMFs in the SEMARNAT offices in Oaxaca City. The documents were sought with the responsible foresters who implement the management plans and have copies of the PMFs. They also allowed me to conduct interviews with them.

With the Foresters, I was able to consult the PMFs, OTCs, and Logging Annual Reports. From the Management Plans, I obtained data such as the quantification and classification of land uses and the methods used to determine these classifications, the silvicultural practices performed, the criteria used to determine areas of production and conservation, in addition to other important information about the forest such as climate, topography, present species, and history of logging activity. I consulted the communities' Logging Annual Reports containing the volumes of timber authorized and harvested each year, for periods of 10 to 20 years (1993-2013) - some of the data from the studied time 
period was not readily available. I also reviewed the communities' Land Zoning Plans, where I looked at the different land uses, as well as methods utilized to determine them and the historic management practices for each of the communities under Forest Management Plans. Some OTCs were obtained from CONAFOR, which had funded them. Eleven of the 23 communities had OTCs, although all necessarily had PMFs.

\subsubsection{Semi-Structured Interviews and Community Visits}

In addition to consulting these primary source materials, I interviewed the Foresters about the management practices in the communities for which they were responsible. I extrapolated much of my qualitative data from these semi-structured interviews. Semi-structured interviews are open ended, though they follow a general script - these are appropriate for occasions when you may not get another chance to interview someone (Bernard 2002), which was the case in many occasions.

To gather data about the 23 communities in my sample, I needed to interview 13 foresters, since many of them are in charge of more than one community. Most Foresters have their offices in Oaxaca City, and in a few cases, I was able to conduct follow up interviews to further check on data.

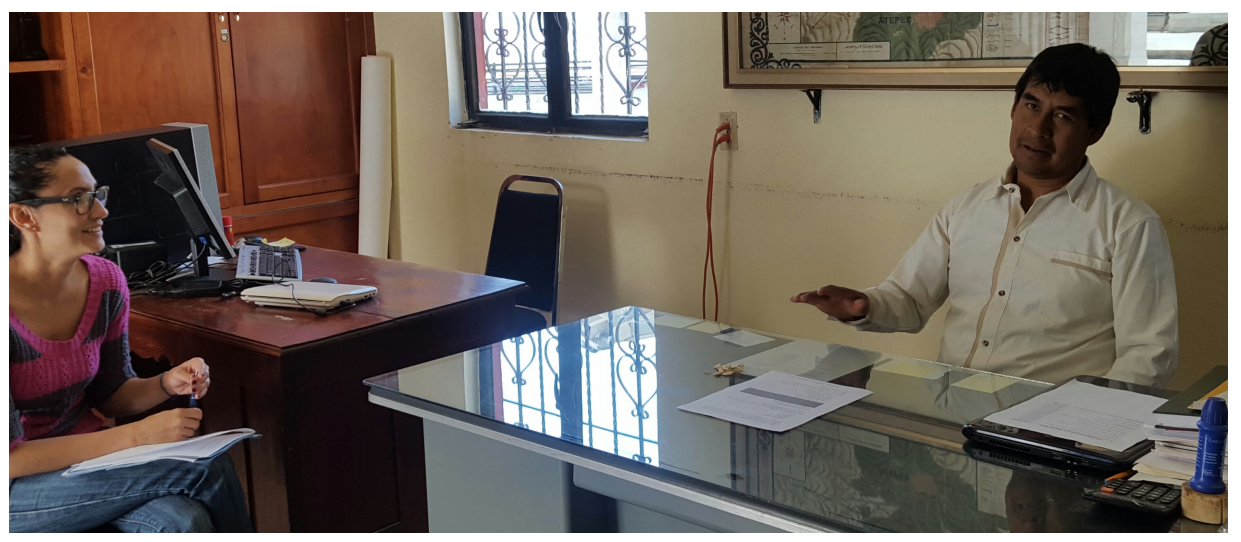

Figure 3: Interview with the Comisariado of San Juan Evangelista Analco. 
The final phase of fieldwork involved visiting a sample of the study communities and interviewing the Comisariados (Heads of Communal Resources) to gather more information on current land use, conservation practices, and on the history and governance of the territory. The communities are all in the Sierra Norte, so this required travel to remote locations. Time constraints did not allow visits to all communities, so a randomly selected sample of 9 communities was visited. I interviewed five of the Comisariados during my stay in the summer and the remaining four when I went back in March. The two survey instruments used in the research, the interview with the Foresters and with the Comisariados, can be found in Appendix I and II.

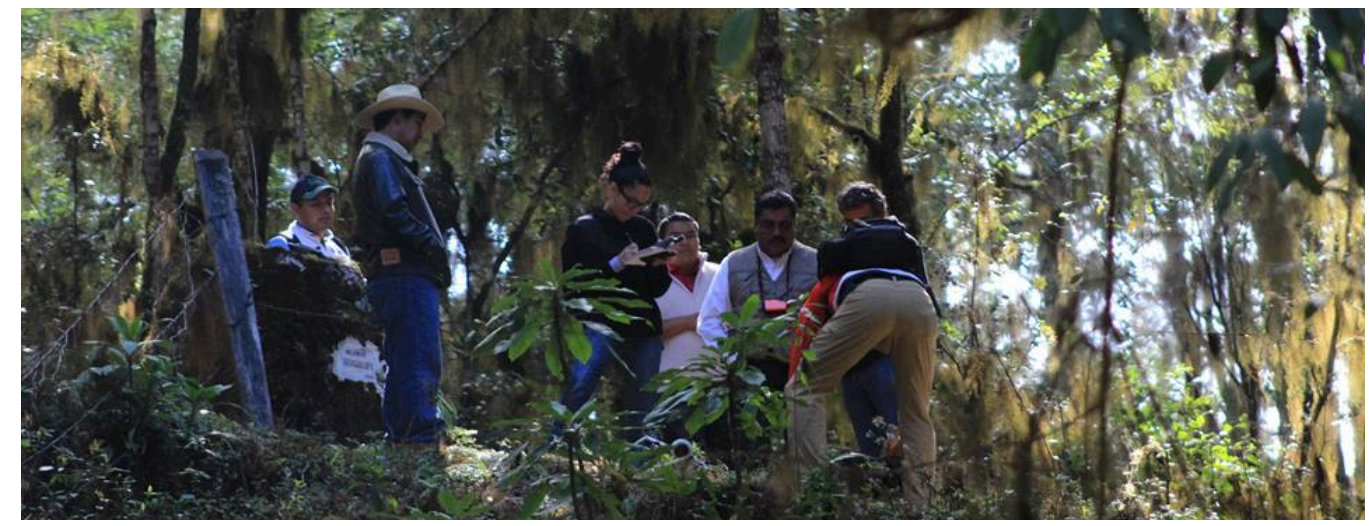

Figure 4: San Juan Evangelista Analco forest visit with Forester and CONAFOR officials.

While in the Sierra to interview the Comisariados, I had some opportunities for informal interviews with community members. I was also able to visit forest management areas and observe the silvicultural practices in production areas, as well as the areas under different forms of conservation. During my visit to the community of San Juan Bautista Atepec, I joined community members in a reforestation activity in which they were participating. 


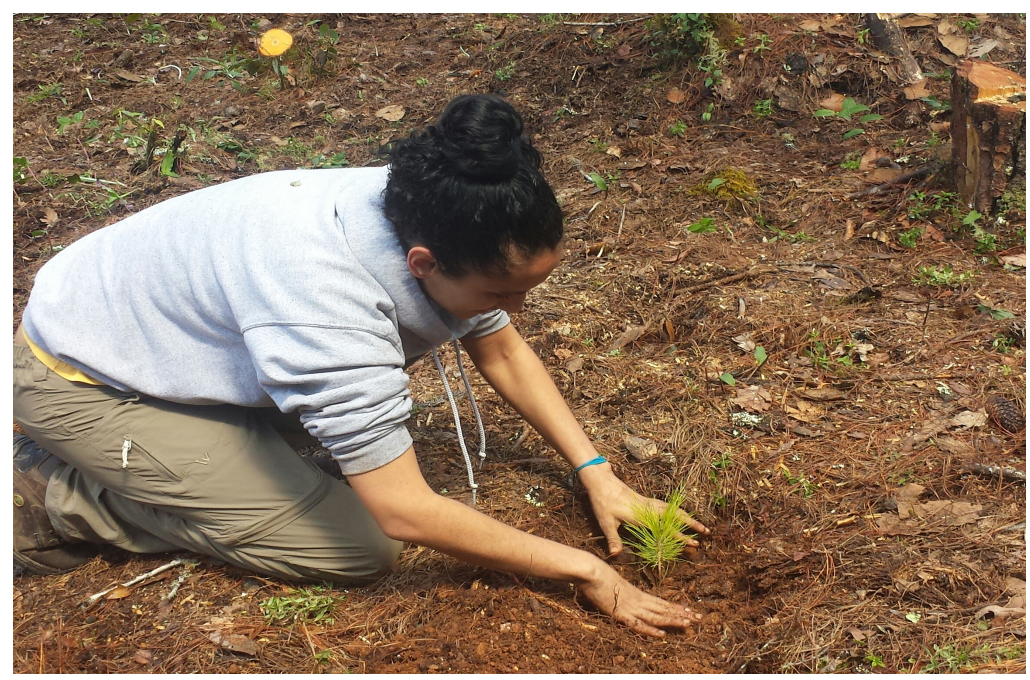

Figure 5: One of 160+ seedlings I planted during a reforestation activity in San Juan Bautista Atepec.

\subsection{Statistical Analysis}

Descriptive data were gathered to demonstrate logging volumes and land uses. All other quantitative data were analyzed using SPSS software. To understand any relationships between dependent and independent variables, and given the small size of my sample, I performed non-parametric tests using Mann-Whitney U, Kruskal-Wallis, and Spearman's Rank-Order Correlation Tests. I analyzed mean ranks and correlation coefficients between: typology, population, population density, size of territory, forested areas, areas under conservation and production, and volumes of timber harvested.

\section{Results}

\subsection{Land-use zoning}

The 23 study communities have a total area of 201,093.94 hectares, of which $156,550.63$ ha, or almost 78\%, is forested. As Figure 6 below shows, 72,030.44 ha are under conservation (36\% of total territory), and $10,237.41$ ha $(5 \%)$ are under restoration. A total of $74,239.30$ hectares $(37 \%)$ are under management for timber production. Of the 
total forest production area, only $29,216.56$ ha were logged in the most recent cycle (2003-2013), consequently leaving 45,022.74 ha of the land "en descanso", or under what can be called "medium-term conservation". The remaining $22 \%$ of the total land, accounting for 44,586.31 hectares, are under "other uses", which include agricultural areas, pastures, and urban areas.

Figure 6: Land-Use Totals

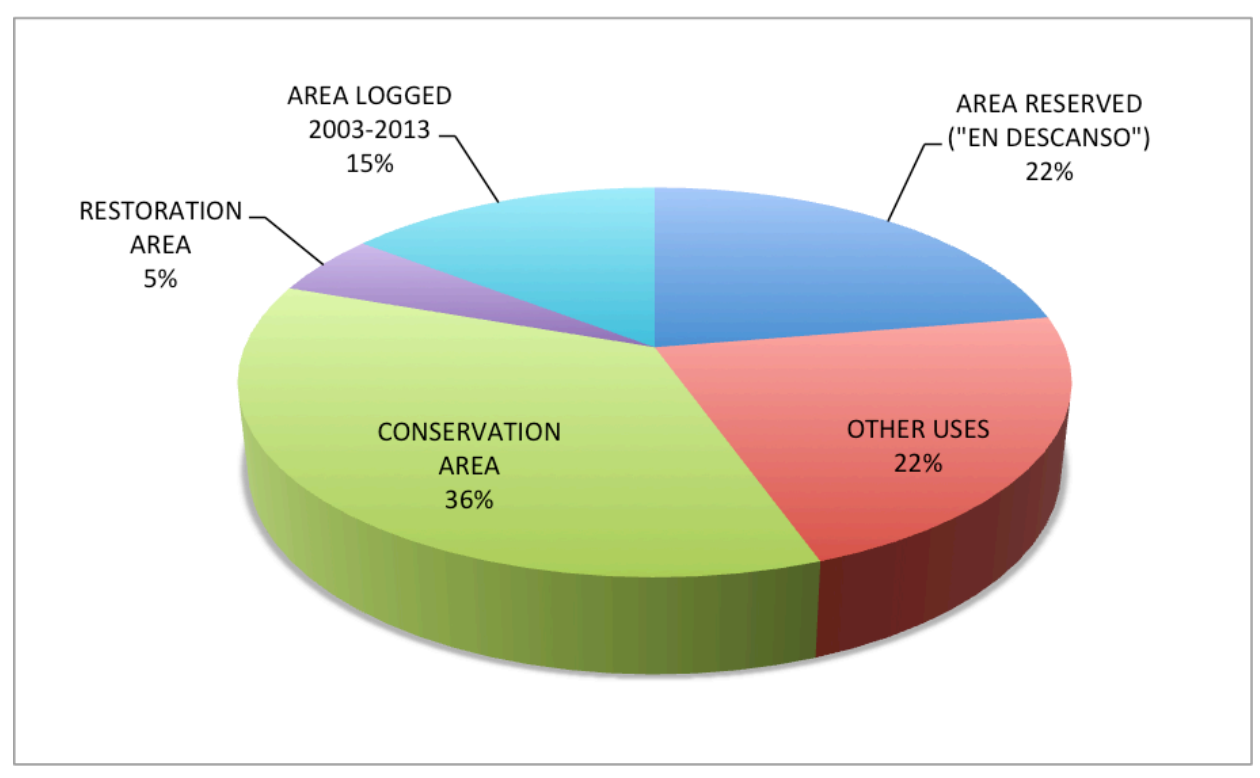

Figure 6: Total land-use types ( $\mathrm{N}=23$ communities).

As depicted in Figure 7, the communities with most forest cover, related to their total territory size are La Trinidad, with $100 \%$ of its territory forested, Zona 1 El Carrizal, with 99\% forest cover, and San Mateo la Reforma, with 97\%. The average forest cover across all communities is $80 \%$ and the median of $83 \%$ cover. The communities with the least forested areas relative to their territory size are Teococuilco de Marcos Perez, with 56\% cover, San Juan Tepanzacoalco, with 44\%, 
and Zona 2 El Carrizal, with only $19 \%$ forest cover. Eighteen out of the 23 communities have over $70 \%$ of their territory forested.

Figure 7: Total Territory vs. Forested Areas (ha)

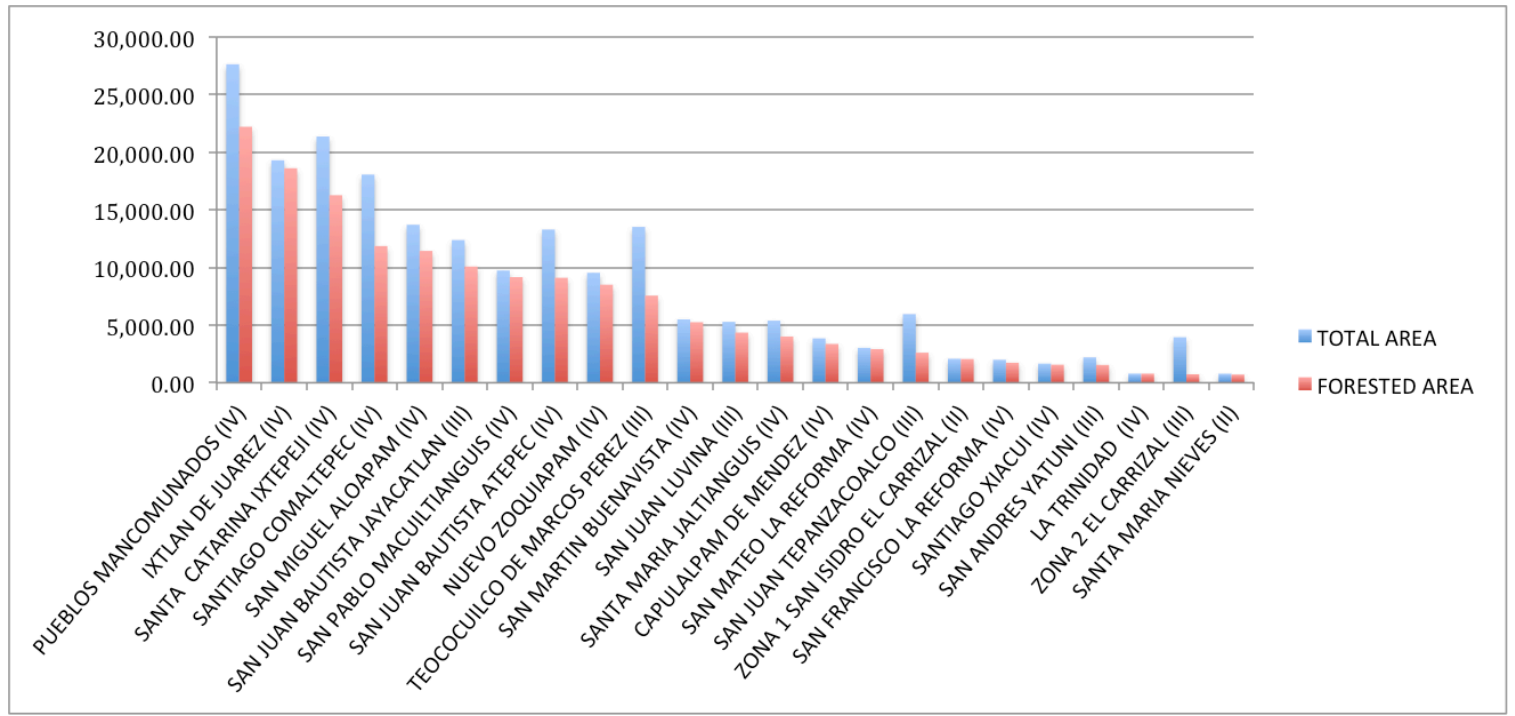

Figure 7: Total territory vs. forested area across communities, in hectares.

Out of the $156,550.63$ hectares of forested land, $46 \%$ is under a form of informal protection and conservation. As can be seen in Figure 8, the percentages of conserved forests relative to their total forested land ranged from Santiago Comaltepec $(86 \%)$, Pueblos Mancomunados (74\%), and San Mateo La Reforma (69\%), with the most area under conservation, to a median of $36 \%$ (Santa Catarina Ixtepeji), to Nuevo Zoquiapam (17\%), and Zona 2 El Carrizal (17\%), and San Juan Bautista Atepec (14\%) with the least, and an average of $40 \%$ conserved forest. Six of the communities have over $50 \%$ of their forested land under conservation, and five of them, close to $50 \%$. Six communities have less than $20 \%$ of their forests under conservation. 
In relation to the total territory, San Mateo La Reforma (67\%), Pueblos Mancomunados (60\%), and Ixtlan de Juarez (58\%), followed by Santiago Comaltepec $(56 \%)$ are the communities with the most conserved forests. San Andres Yatuni (14\%), San Juan Bautista Atepec (9\%), and Zona 2 El Carrizal (3\%) account for the least conserved areas in relation to total territory.

Figure 8: Percentages of Conservation and Production Areas

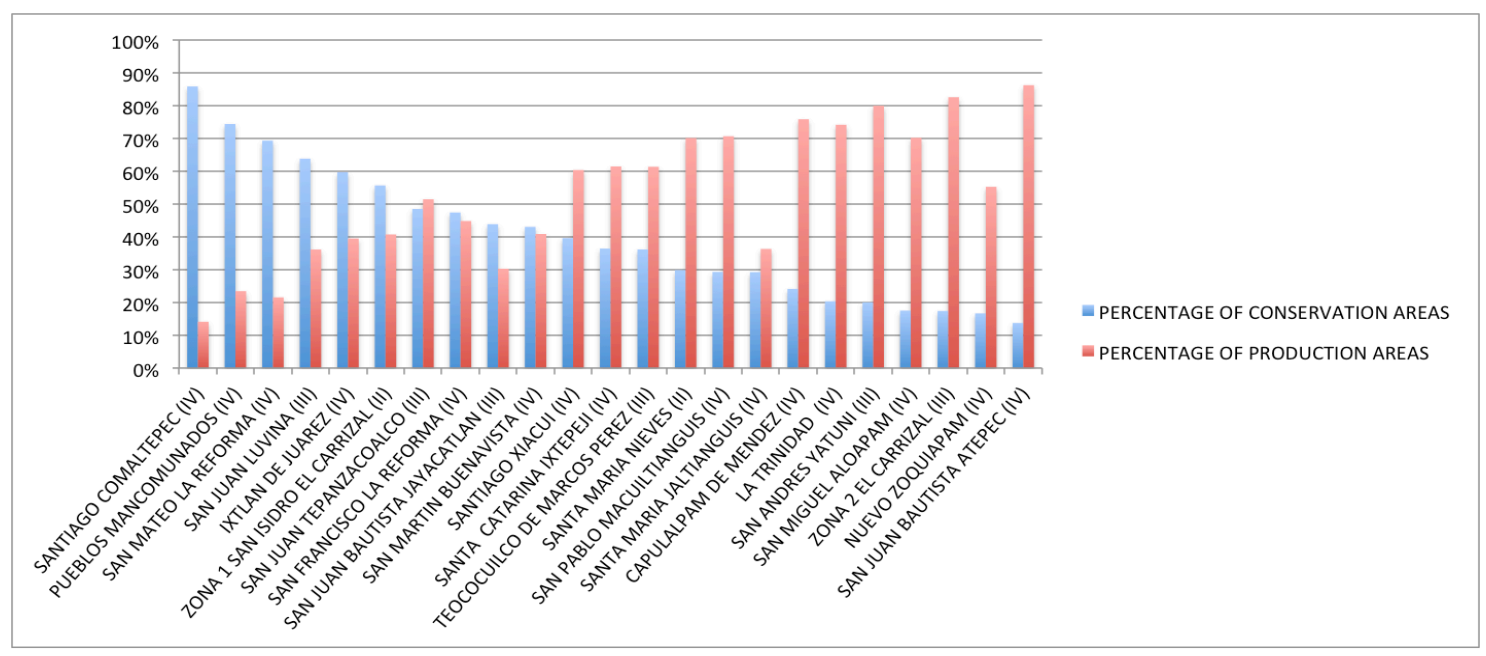

Figure 8: Percentages of total conservation and production areas across all 23 communities, relative to total forested land.

Production areas account for $47 \%$ of the total forested land. As depicted in Figure 8 above, San Juan Bautista Atepec (86\%), Zona 2 El Carrizal (83\%), and San Andres Yatuni $(80 \%)$ were found to be the communities with the largest percentage of land allocated for production; Santiago Comaltepec (14\%), San Mateo La Reforma (22\%), and Pueblos Mancomunados (23\%) have the least areas under management for production; with a median of $55 \%$ and average of $53 \%$ of land allocated for timber production, relative to total forested land. As figure 8 shows, 9 of the communities have more forests 
under conservation than in production, while 14 of them have more area under management for timber production than in conservation.

However, as noted, the production areas can be divided into the areas under the last ten-year management plan (2003-2013) and the remaining forest that is reserved for future harvest cycles in 40-60 year turns. On average, communities only logged on about $39 \%$ of the land allotted for timber production during the last management plan, thus leaving over $60 \%$ of the forest within production areas untouched until future harvest cycles.

Figure 9: Production vs. Logged vs. Reserved (ha)

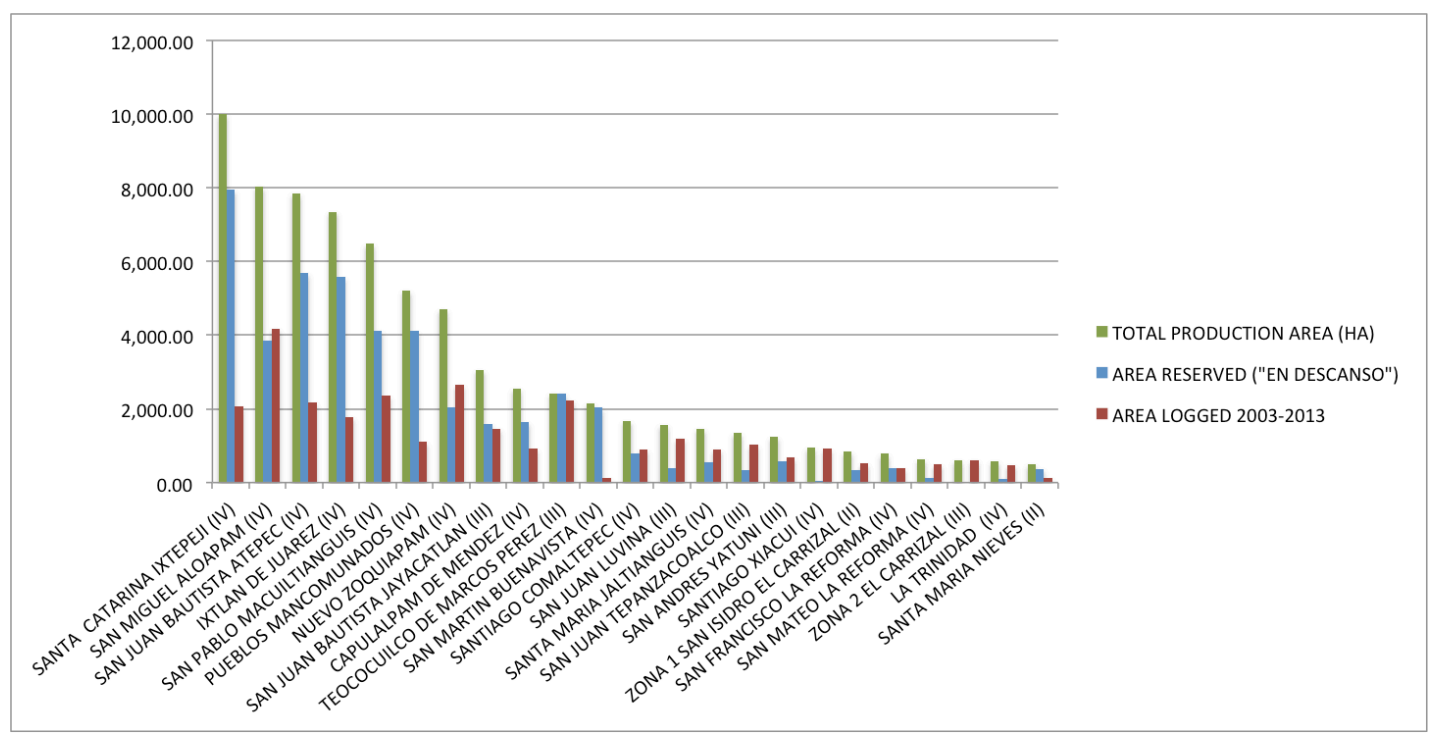

Figure 9: Total production areas, areas logged 2003-2013, and areas reserved (under "medium-term conservation"), in hectares.

Communities with larger production areas tend to have smaller areas under conservation. However, as it can be seen in Figure 10, below, even when conservation areas are small, forests are still being conserved within production 
areas. Thus, between areas under permanent (46\% of forest area) and under what I call "medium-term conservation" (29\%), a total of $117,053.19$ ha of forest is under some form of conservation at a given time between logging cycles.

\section{Figure 10: Total Forest Under Conservation}

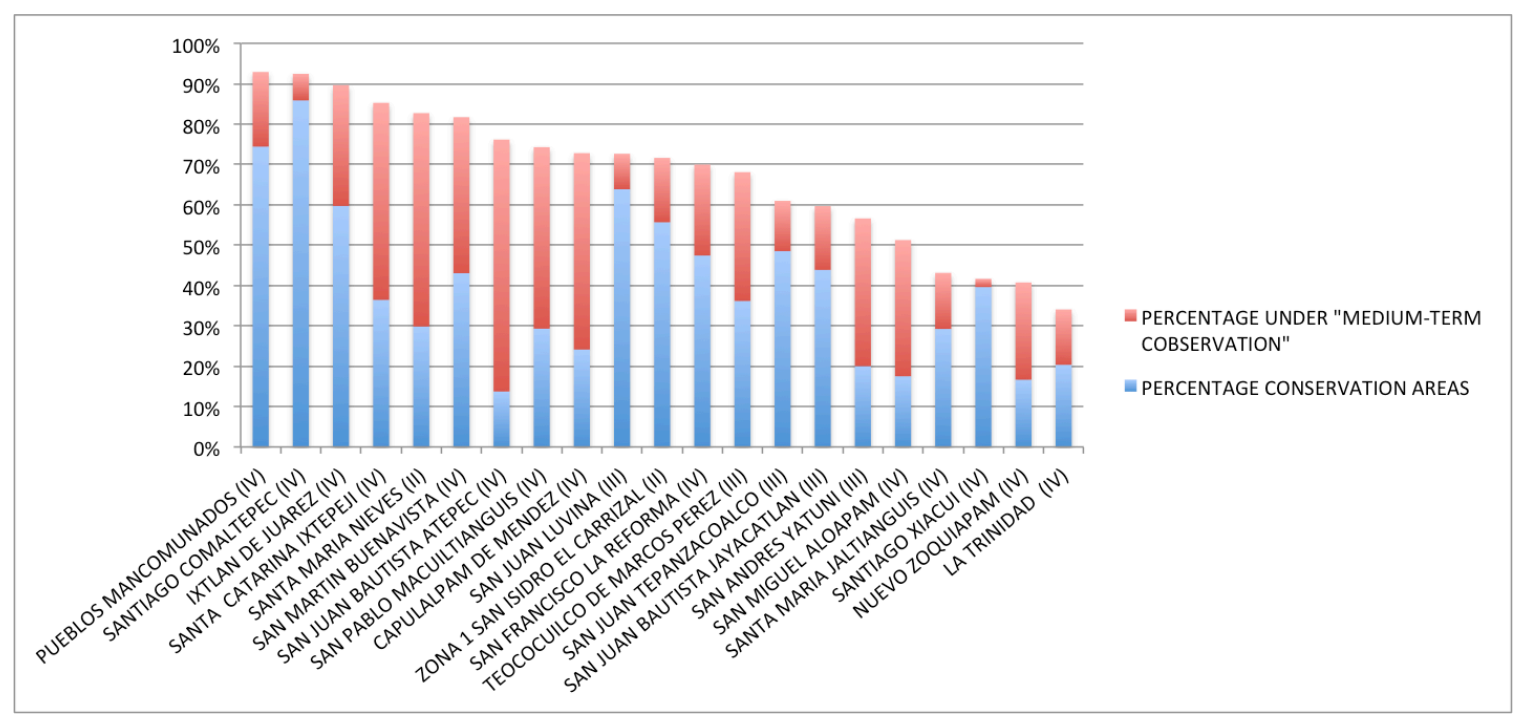

Figure 10: Total forested area under permanent conservation and medium-term conservation.

\subsection{Timber Volumes Harvested}

In addition to land use zones, I also sought to quantify the flow of timber being produced in SNO's forests for periods of 10 to 20 years (1993-2003 and 2003-2013) ${ }^{1}$. I acquired data from 2003 to 2013 for 21 out of the 23 communities in my sample (all but Zona 2 El Carrizal, which I only obtained data from 1993 to 2003, and San Mateo La Reforma, for which I was not able to gather sufficient logging data). I found that during

\footnotetext{
${ }^{1}$ Harvest "years" are calculated over two years, so 2003 is actually 2003-2004, 2013 is

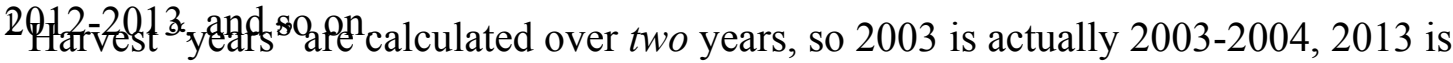
2012-2013, and so on.
} 
that period, these communities harvested a total of $1,503,339.15 \mathrm{~m}^{3}$ of timber (about $70 \%$ consisting of Pinus species).

For the previous ten-year period, from 1993 to 2003, I only obtained data for 13 out of the 23 communities. I found that during that period, these 13 communities logged a total of $950,357.39 \mathrm{~m}^{3}$, also consisting mainly of Pinus. Data collected for volumes harvested are displayed in Figure 11 below.

Figure 11: Timber Volumes Harvested 1993-2003 and 2003-2013 $\left(\mathrm{m}^{3}\right)$

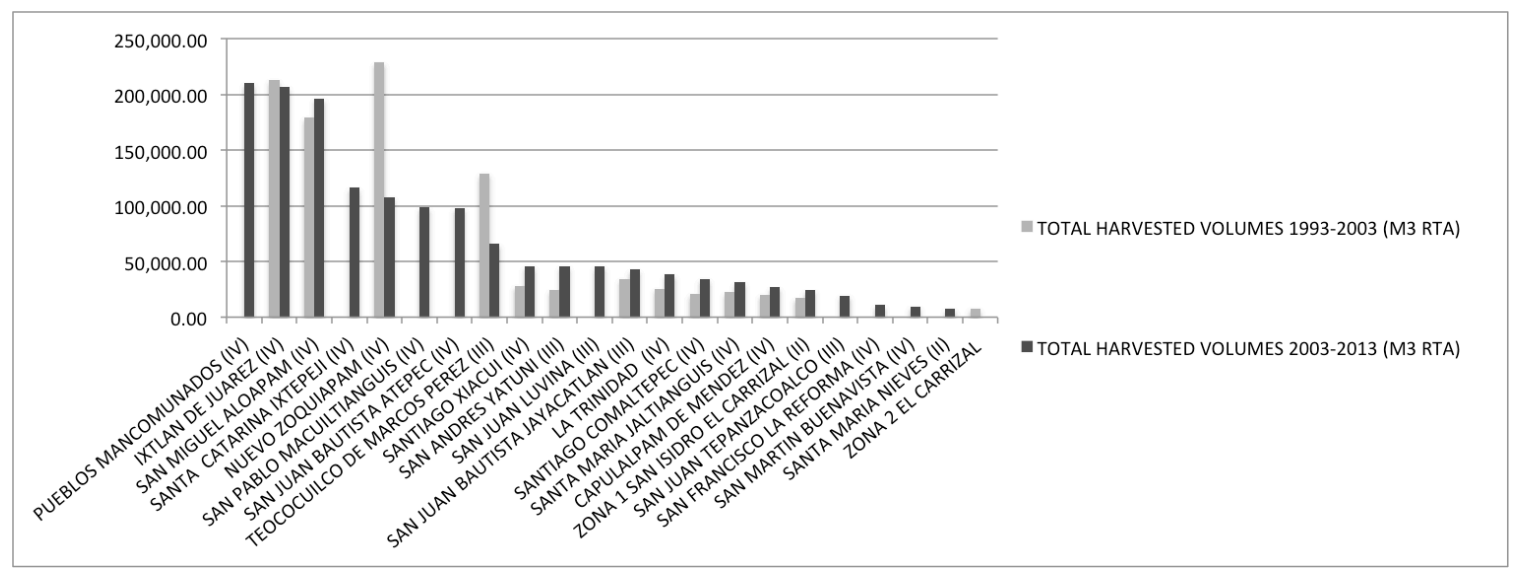

Figure 11: Total volumes harvested (in cubic meters) between 1993-2003 and 2003-2013, accounting for 22 communities: 21 communities with data from 2003-2013, 12 of those with data from both periods, and 1 community with data only from 1993-2003 (Zona 2 El Carrizal).

On the basis of the data provided by the 12 communities with 20 -year logging data, it can be said that a minimum of $1,808,620.66 \mathrm{~m}^{3}$ were harvested from SNO over the 20 -year period. In the first ten years, these communities harvested a total of $49 \%$ of the timber volumes they were authorized to $\log \left(942,335.11 \mathrm{~m}^{3}\right.$ harvested out of $1,925,067.10 \mathrm{~m}^{3}$ authorized), or an average of $59 \%$ of the authorized volumes. 
Figure 12: Timber Volumes Authorized and Harvested 1993-2003

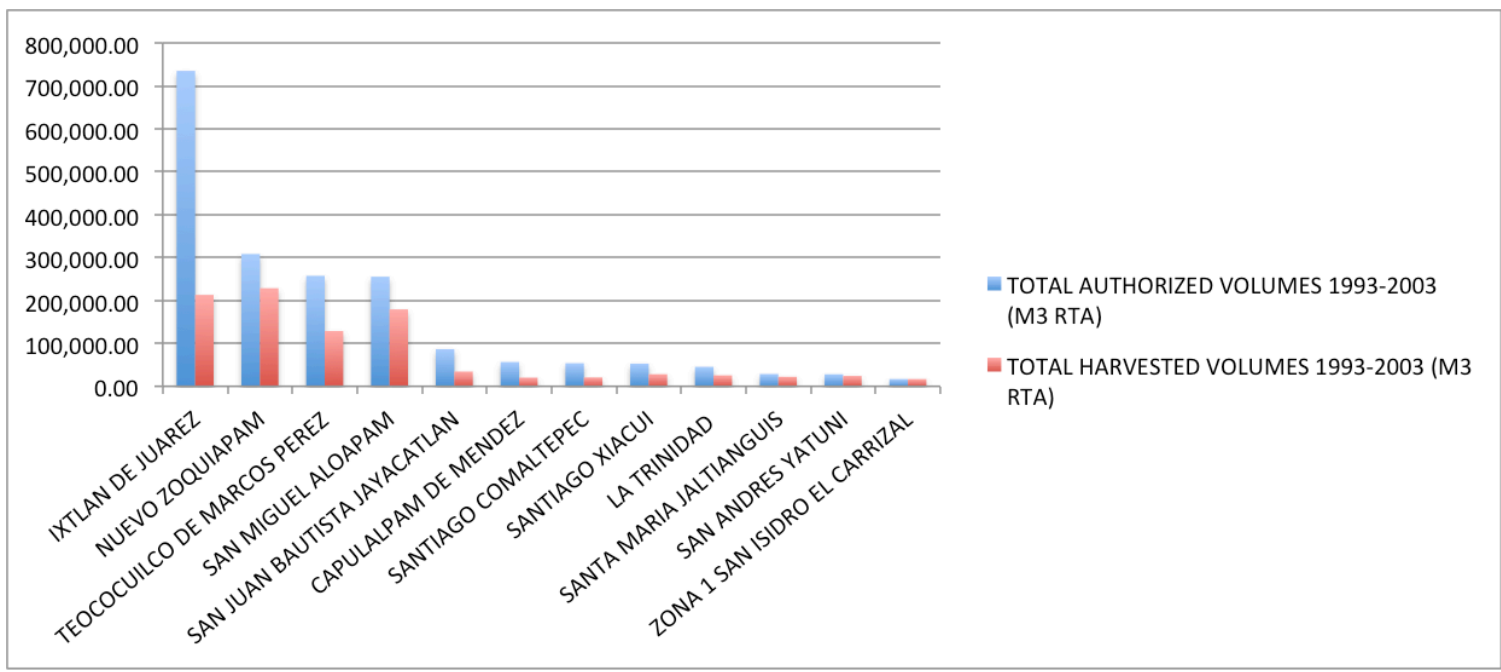

Figure 12: Total volumes authorized and volumes actually harvested from 1993 to $2003(\mathrm{~N}=12)$

If a similar percentage harvested out of volumes authorized for the communities with missing data in the first ten years (and following period for Zona 2 El Carrizal) is assumed, which would come out to $59 \%$ of $839,694.85 \mathrm{~m}^{3}$ (authorized volumes $03-13$ for communities with missing data), a harvested volume of $495,419.96 \mathrm{~m}^{3}$ for the missing communities can be estimated. This calculation would give an estimated volume harvested of $1,445,777.35 \mathrm{~m}^{3}$ for all communities in the first ten-year period (19932003), and a volume of $1,503,339.15 \mathrm{~m}^{3}$ from 2003-2013, thus proposing an estimated total volume harvested of $2,949,116.50 \mathrm{~m}^{3}$ for the full 20 years between the communities with logging data.

Through the interviews, I compiled data regarding the reasons communities usually logged below the volumes they were authorized at a given harvest cycle. I gathered this information for 19 out of the 21 communities in my logging database. Four of the communities were not applicable because they are logging $100 \%$ of the authorized 
volumes, or close to it (Pueblos Mancomunados, San Martin Buenavista, Santa Maria Nieves, and Zona 1 El Carrizal). The remaining communities do not harvest all the timber they are authorized for a variety of reasons, such as lack of laborers or resources (three of the communities: San Juan Bautista Atepec, San Juan Luvina, and San Pablo Macuiltianguis), issues with access and lack of organization (Ixtlan de Juarez), or lack of efficiency (San Andres Yatuni). However, I found that over half (10 out of the 19 communities) made the conscious decision to not log more, in order to conserve their resources.

Figure 13: Reasons for Logging Below Authorized Volumes

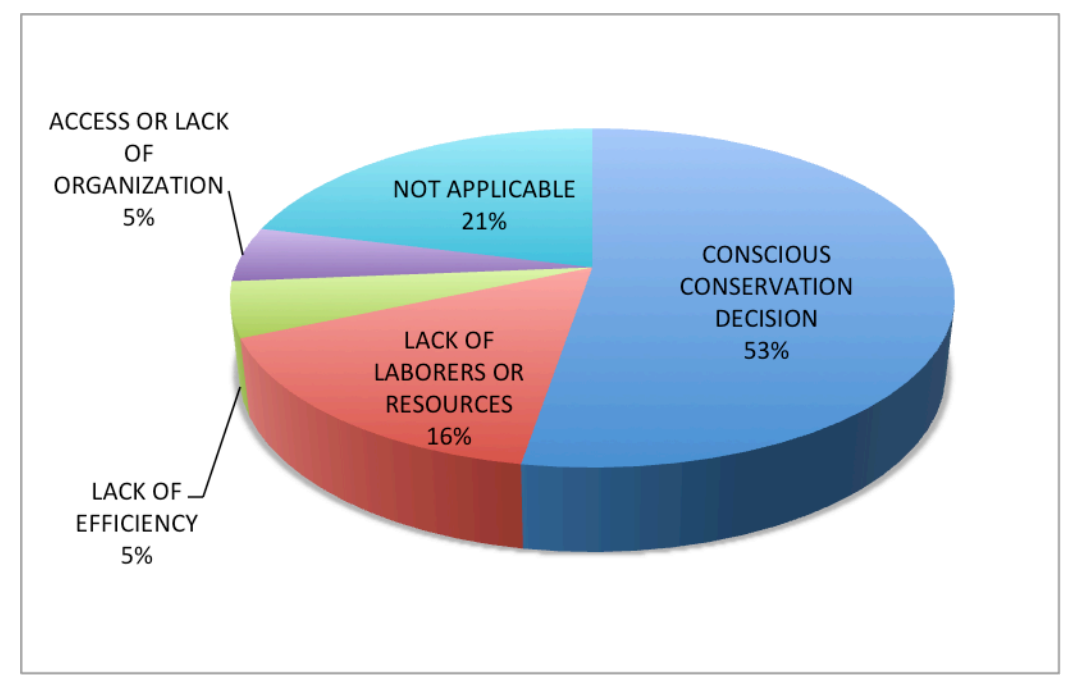

Figure 13: Reasons why communities harvest below authorized volumes of timber across 19 of the logging communities

\subsection{Statistical Analysis of Land Use and Timber Volumes}

\subsubsection{Typology vs. Land Use and Timber Harvested}

By performing Mann-Whitney U and Kruskal-Wallis Tests, I found that the more vertically communities (community type) had no correlation with the size of total 
territory (Kruskal-Wallis p-value $<.14$ ) or the forested area (Kruskal-Wallis p-value < .10 ), and it had no influence on the size of production areas (Kruskal-Wallis p-value < .11 ) or of areas under conservation (Kruskal-Wallis p-value $<.34$ ).

Table 3: Mann-Whitney U and Kruskal-Wallis Tests Results

\begin{tabular}{ccccc}
\hline Variable & Mean & Std. Deviation & $\begin{array}{c}\text { Mann-Whitney } \\
\text { p-value }\end{array}$ & $\begin{array}{c}\text { Kruskal- } \\
\text { Wallis } \\
\text { p-value }\end{array}$ \\
\hline Total Area & $9,108.91$ & $7,728.20$ & .517 & .139 \\
\hline $\begin{array}{c}\text { Forested } \\
\text { Area }\end{array}$ & $6,806.55$ & $6,079.44$ & .161 & .091 \\
\hline $\begin{array}{c}\text { Conservation } \\
\text { Area }\end{array}$ & $3,131.76$ & $4,131.90$ & .697 & .337 \\
\hline $\begin{array}{c}\text { Production } \\
\text { Area }\end{array}$ & $3,227.79$ & $2,927.81$ & .243 & .102 \\
\hline
\end{tabular}

Table 3: Relationship between typology, size of total territory, forested area, conservation area, and production area. Results showed no correlation between the variables $(\mathrm{N}=21)$

By performing one-way ANOVA and Kruskal-Wallis Tests with each of the community types, from II to IV, I found that typology also had no influence on the volumes of timber harvested in the last ten-year plan, from 2003 to 2013, with a KruskalWallis p-value $<.13$. 
Table 4: ANOVA and Kruskal-Wallis Tests Results

\begin{tabular}{cccccc}
\hline Type & Mean $\left(\mathbf{m}^{\mathbf{3}}\right)$ & $\begin{array}{c}\text { Std. } \\
\text { Deviation }\end{array}$ & $\begin{array}{c}\text { ANOVA } \\
\text { p-value }\end{array}$ & $\begin{array}{c}\text { Mean } \\
\text { Ranks }\end{array}$ & $\begin{array}{c}\text { Kruskal- } \\
\text { Wallis } \\
\text { p-value }\end{array}$ \\
\hline $\begin{array}{c}\text { Type II } \\
(\mathrm{N}=2)\end{array}$ & $15,867.11$ & $11,786.57$ & .197 & 3.00 & $\mathbf{. 1 2 6}$ \\
\hline $\begin{array}{c}\text { Type III } \\
(\mathrm{N}=5)\end{array}$ & $43,856.90$ & $16,492.27$ & .197 & 10.20 & $\mathbf{. 1 2 6}$ \\
\hline $\begin{array}{c}\text { Type IV } \\
(\mathrm{N}=14)\end{array}$ & $87,942.24$ & $72,501.74$ & .197 & 12.43 & $\mathbf{. 1 2 6}$ \\
\hline
\end{tabular}

Table 4: Relationship between typology and timber volumes harvested from 2003 to 2013. Results showed no correlation between the two variables $(\mathrm{N}=21)$

\subsubsection{Territory Size and Population Density vs. Land Use and Timber Harvested}

Spearman's Rank-Order Correlation Tests were done to find relationships between all variables, excluding typology, which had already been done. These include total area, population, population density, forested areas, areas under conservation and production areas, areas logged in the last ten year plan (last 10-year harvest cycle, 20032013), the remaining land within production area that was not logged (area under "medium-term conservation"), as well as the volumes of timber harvested in the last tenyear plan.

By evaluating bivariate-level, non-parametrical rank correlation coefficients, I found that both territory size and population had an influence on the total volumes of timber harvested in the last ten-year management plan and harvest cycle - population more strongly than size of territory (total area). Both population and total area showed a strong positive correlation with all the variables analyzed, however, population size alone 
would not be the most important variable. Ixtlan de Juarez, for instance, has the largest population in the Sierra, but also a very large territory, so population density is low.

Contrary to what I had hypothesized, population density did not show a correlation with any of the variables, save for conservation areas. A strong negative correlation showed that generally, the more densely populated communities are, the smaller areas under conservation they have. On the other hand, the more populated (and larger) areas did prove to have the larger forested areas, larger production and conservation areas, and to be harvesting higher volumes of timber. All relationships were significant at the .05 level ( $\mathrm{p}$-values were all $<.05$ ), with exception of population density. Correlation coefficients range between -1 (strong negative relationship) and 1 (strong positive relationship), with 0 meaning no correlation. Table 5 below shows results of the Spearman's Rank-Order Correlation Test.

Table 5: Spearman's Rank-Order Correlation Test Results

\begin{tabular}{|c|c|c|c|c|c|c|c|c|c|c|}
\hline Vari & & $\begin{array}{l}\text { Total } \\
\text { Area }\end{array}$ & $\begin{array}{l}\text { Population } \\
\text { (2010) }\end{array}$ & $\begin{array}{c}\text { Population } \\
\text { Density }\end{array}$ & $\begin{array}{c}\text { Forested } \\
\text { Area }\end{array}$ & $\begin{array}{c}\text { Conservation } \\
\text { Area }\end{array}$ & $\begin{array}{c}\text { Total } \\
\text { Production } \\
\text { Area }\end{array}$ & $\begin{array}{c}\text { Tenure } \\
\text { Plan } \\
\text { Logging }\end{array}$ & $\begin{array}{c}\text { Medium- } \\
\text { Term } \\
\text { Conservation }\end{array}$ & $\begin{array}{c}\text { Timber } \\
\text { Volumes } \\
\text { Harvested }\end{array}$ \\
\hline Total Area & $\begin{array}{l}\text { Correlation } \\
\text { Coefficient }\end{array}$ & - & $.788^{* *}$ & -.386 & $.963 * *$ & $.881^{* *}$ & $.874 * *$ & $.614 * *$ & $.860^{* *}$ & $.709 * *$ \\
\hline & P-value & - & .000 & .103 & .000 & .000 & .000 & .005 & .000 & .001 \\
\hline Population & $\begin{array}{l}\text { Correlation } \\
\text { Coefficient }\end{array}$ & $.788^{* *}$ & - & .273 & $.726^{* *}$ & $.503^{*}$ & $.747^{* *}$ & $.665 * *$ & $.639 * *$ & $.823 * *$ \\
\hline & P-value & .000 & . & .232 & .000 & .020 & .000 & .001 & .002 & .000 \\
\hline Population & $\begin{array}{l}\text { Correlation } \\
\text { Coefficient }\end{array}$ & -.386 & .273 & - & -314 & $-.569 * z$ & -.186 & -.087 & -.249 & .113 \\
\hline Density & P-value & .103 & .232 & . & .177 & .007 & .420 & .708 & .276 & .626 \\
\hline Forested Area & $\begin{array}{l}\text { Correlation } \\
\text { Coefficient }\end{array}$ & $.963 * *$ & $.726^{* *}$ & -.314 & - & $.902 * *$ & $.868 * *$ & $.647 * *$ & $.803^{* *}$ & $.746^{* *}$ \\
\hline & P-value & .000 & .000 & .177 & - & .000 & .000 & .002 & .000 & .000 \\
\hline Conservation & $\begin{array}{l}\text { Correlation } \\
\text { Coefficient }\end{array}$ & $.881^{* *}$ & $.503^{*}$ & $-.569 * *$ & $.902^{* *}$ & - & $.687^{* *}$ & $.508^{*}$ & $.631^{* *}$ & $.532^{*}$ \\
\hline & P-value & .000 & .020 & .007 & .000 & - & .001 & .019 & .002 & .013 \\
\hline $\begin{array}{c}\text { Total } \\
\text { Production }\end{array}$ & $\begin{array}{l}\text { Correlation } \\
\text { Coefficient }\end{array}$ & $.874^{* *}$ & $.747^{* *}$ & -.186 & $.868 * *$ & $.687^{* *}$ & - & $.810^{* *}$ & $.918 * *$ & $.755^{* * *}$ \\
\hline & P-value & .000 & .000 & .420 & .000 & .001 & - & .000 & .002 & .000 \\
\hline Tenure Plan & $\begin{array}{l}\text { Correlation } \\
\text { Coefficient }\end{array}$ & $.614^{* *}$ & $.665 * *$ & -.087 & $.647 * *$ & $.508^{*}$ & $.810^{* *}$ & - & $.657^{* *}$ & $.794 * *$ \\
\hline Logging Area & P-value & .005 & .001 & .708 & .002 & .019 & .000 & - & .001 & .000 \\
\hline $\begin{array}{l}\text { Medium-Term } \\
\text { Conservation }\end{array}$ & $\begin{array}{l}\text { Correlation } \\
\text { Coefficient }\end{array}$ & $.860^{* *}$ & $.6399^{* *}$ & -249 & $.803^{* *}$ & $.631^{* *}$ & $.918^{* *}$ & $.657 * *$ & - & $.677 * *$ \\
\hline Area & P-value & .000 & .002 & .276 & .000 & .002 & .000 & .001 & - & .001 \\
\hline $\begin{array}{l}\text { Timber } \\
\text { Volumes }\end{array}$ & $\begin{array}{l}\text { Correlation } \\
\text { Coefficient }\end{array}$ & $.709 * *$ & $.823 * *$ & .113 & $.746^{* *}$ & $.532^{*}$ & $.755 * *$ & .794 & $.677 * *$ & - \\
\hline Harvested & P-value & .001 & .000 & .626 & .000 & .013 & .000 & .000 & .001 & - \\
\hline
\end{tabular}

Table 5: Spearman's Rank-Order Correlation Test results, looking at relationships between total area, population, and population density, and all other dependable variables across the sample. ${ }^{* *}$ Correlation is significant at the 0.01 level (2-tailed). ${ }^{*}$ Correlation is significant at the 0.05 level (2-tailed). 


\subsection{Management Practices and Conservation}

Conservation in SNO communities is also influenced by the silvicultural practices in the logging areas. Out of the 23 communities in the database, eight use MDS (more intensive logging, 35\%), five of them use MMOBI (less intensive, 22\%), four SICODESI (similar to MDS, 17\%), and six of them use a combination of MDS and MMOBI practices ("mixed methods", 26\%). Regardless of their silvicultural practices, I found that all of the communities follow certain standards in their management plans. They all evaluate and monitor regeneration in the areas that were recently logged; they manually reforest areas where natural regeneration did not occur, planting from 1,111 to 2,500 trees per hectare; they all implement fire prevention, pest control, soil erosion prevention, and flora and fauna protection measures; and all perform directional felling.

Both PMFs and OTCs have no-standardized approaches to classifying conservation areas. Categories used in the FMPs include: 1) flora and fauna habitat protection, 2) riparian buffer zones, 3) slopes greater than $100 \%$ or $\left.45^{\circ}, 4\right)$ areas over 3000 meters above sea level, 5) cloud forests, 6) recreation areas, and in some cases 7) areas of high conservation value. The OTCs were not used in the quantitative analysis, but are operative in 11 of the communities, and their conservation categories include: 1) preservation areas, 2) watershed protection, 3) recreation/ecotourism areas, 4) "seed areas" (areas semilleras) 5) inaccessible areas, 6) flora and fauna protection, 7) cultural sites, 8) threatened/endangered species protection, among others. The range of criteria used in determining conservation areas in these communities suggests a detailed attention to the preservation of their forests and all species within them. 
Nine of the communities are either actively certified under the Forest Stewardship Council (FSC) or in the process of getting certified. Forests under FSC certification follow global set standards for responsible forest management. The benefits of the certification include credibility and access to markets, as many major companies prefer FSC-certified products; environmental protection (protection is expanded to water quality, prohibition of harvests in rare old-growth forests, and prohibition of use of hazardous chemicals); and community engagement (FSC 2016).

In addition, between 2009 and 2013, seven communities in SNO received financial assistance from PSAH, shown below in Figure 14. These communities received about US\$ $1,900,000$ to contribute with the enhancement of hydrological resources, covering a total of $13,507.81$ hectares of forested land.

Figure 14: Payment for Ecosystem Services in SNO 2009-2013

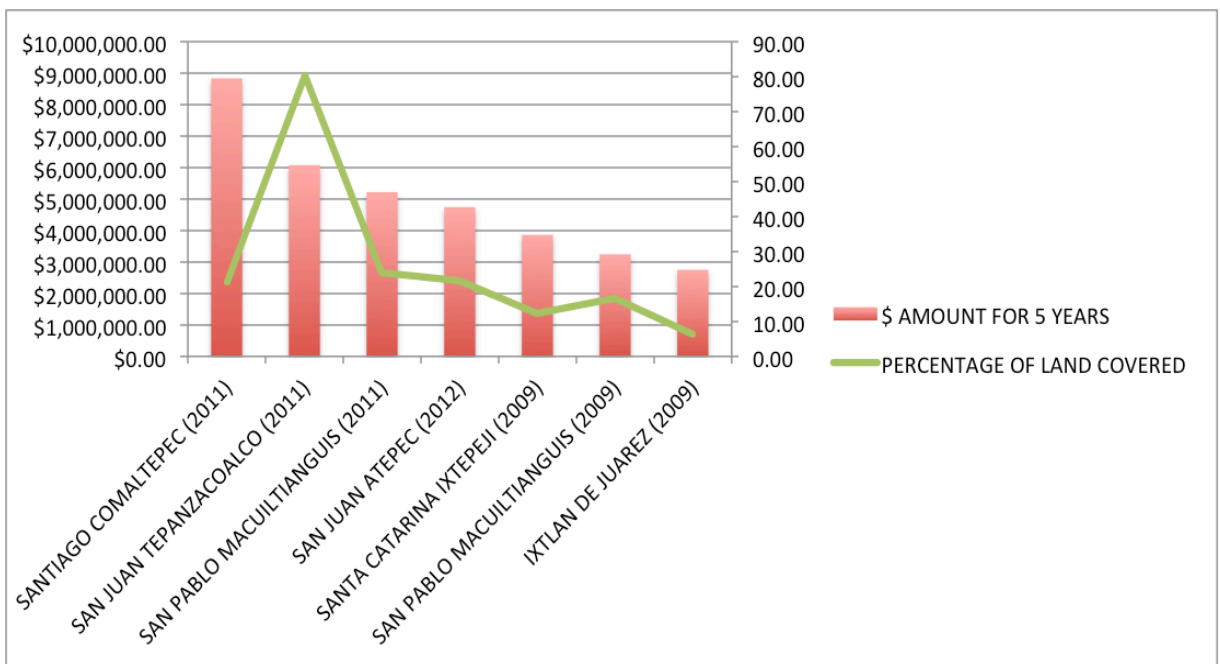

Figure 14: Logging communities in Sierra Norte that received financial assistance from PES, between 2009 and 2013. 
Active timber production areas are managed in 10 years plans, and applied in logging cycles over $40-60$ years. Thus, only a fraction of the production area is logged over a ten year period, with only particular annual stands logged every cycle, leaving large part of the production forest in recovery from logging for long periods of time. This practice is similar to a fallow period, as applied in agricultural systems in order to restore soil fertility and allow for regeneration. Because production areas are typically intentionally not harvested to their fullest extent, intensity and impacts of logging are reduced.

As a measure of logging intensity, I looked at the relationship between the size of recent logging areas (2003-2013 ten-year plan), and volumes of timber harvested per hectare during that period. Figure 15 shows the intensity of logging (volumes logged per hectare) relative to the area that was logged from 2003 to 2013 (ha). As it can be seen, San Miguel Aloapam has the largest logging area (4,172.2 ha), however they logged the least intensively during the ten-year plan $\left(47.08 \mathrm{~m}^{3} / \mathrm{ha}\right)$. San Martin Buenavista on the other hand, is shown to be the community logging most intensively $\left(82.26 \mathrm{~m}^{3} / \mathrm{ha}\right)$, as compared to its small logging area (116.33 ha). Logging intensity was determined by dividing the area logged in the last ten-year plan by the volume harvested during that period. 
Figure 15: Logging Intensity $\left(\mathrm{m}^{3} / \mathrm{ha}\right)$

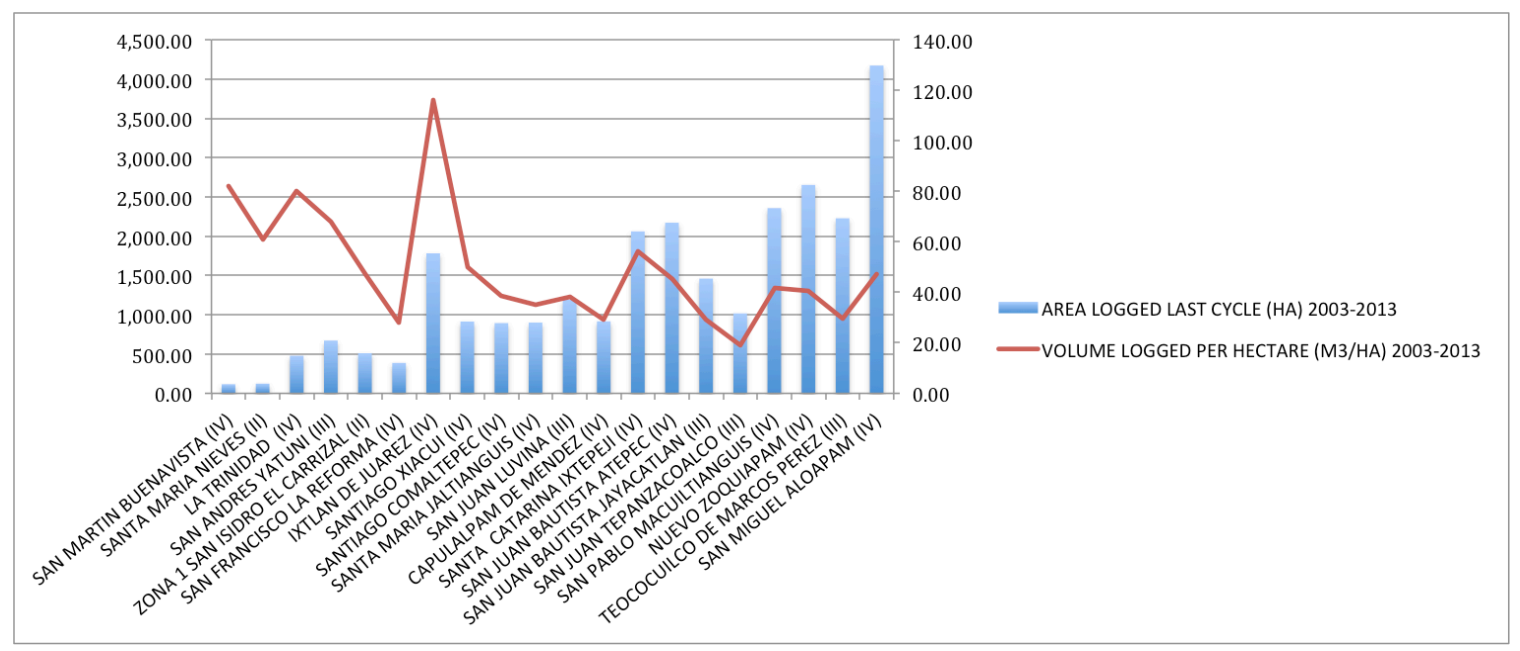

Figure 15: Timber volumes harvested $\left(\mathrm{m}^{3}\right)$ per hectare of logged areas during last ten-year plan, 2003-2013, depicting logging intensity.

Across all communities, the average logging intensity was $55.86 \mathrm{~m}^{3} / \mathrm{ha}$, out of a total area logged of $28,113.04$ hectares. The communities that logged most intensively in the last ten-year plan (2003-2013) were San Martin Buenavista ( $82 \mathrm{~m}^{3} / \mathrm{ha}$, on $\left.116.33 \mathrm{ha}\right)$ and Santa Maria Nieves $\left(61.08 \mathrm{~m}^{3} / \mathrm{ha}\right.$, on $\left.123.33 \mathrm{ha}\right)$. The communities logging least intensively were San Miguel Aloapam (47 m³ ha, on 4,172.20 ha) and Teococuilco de Marcos Perez (29.52 $\mathrm{m}^{3} / \mathrm{ha}$, on 2,228.16 ha).

Table 6 below shows these four communities and other variables pertaining to their management practices. The descriptive statistics show a variation in the silvicultural systems, the intensity of logging, and areas under production and conservation. In the Discussion section I will discuss this table and explore the implications of the silvicultural methods in these communities. 
Table 6: Most and Least Intensive Logging

\begin{tabular}{|c|c|c|c|c|}
\hline \multirow[b]{2}{*}{$\begin{array}{c}\text { Community/ } \\
\text { Type }\end{array}$} & \multicolumn{2}{|c|}{ Most Intensive Logging } & \multicolumn{2}{|c|}{ Least Intensive Logging } \\
\hline & Buenavista (IV) & Nieves (II) & Aloapam (IV) & Teococuilco (III) \\
\hline $\begin{array}{c}\text { Volume Logged per } \\
\text { Hectare (Within } \\
\text { Logging Area) }\end{array}$ & $82 \mathrm{~m}^{3} / \mathrm{ha}$ & $61.08 \mathrm{~m}^{3} / \mathrm{ha}$ & $47 \mathrm{~m}^{3} / \mathrm{ha}$ & $29.52 \mathrm{~m}^{3} / \mathrm{ha}$ \\
\hline $\begin{array}{c}\text { Ten-year Plan Logging } \\
\text { Area (Within } \\
\text { Production) }\end{array}$ & 116.33 ha $(5 \%)$ & 123.33 ha $(25 \%)$ & $4,172.20$ ha $(52 \%)$ & $2,228.16$ ha $(48 \%)$ \\
\hline Timber Harvested $\left(\mathrm{m}^{3}\right)$ & $9,569.05$ & $7,532.74$ & $196,425.38$ & $65,775.25$ \\
\hline $\begin{array}{c}\text { Medium-Term } \\
\text { Conservation (Within } \\
\text { Production) }\end{array}$ & $95 \%$ & $75 \%$ & $48 \%$ & $52 \%$ \\
\hline $\begin{array}{l}\text { Percentage Under } \\
\text { Production (Within } \\
\text { Forest) }\end{array}$ & $41 \%$ & $70 \%$ & $70 \%$ & $61 \%$ \\
\hline $\begin{array}{c}\text { Percentage Under } \\
\text { Conservation (Within } \\
\text { Forest) }\end{array}$ & $43 \%$ & $30 \%$ & $18 \%$ & $36 \%$ \\
\hline Silvicultural System & MDS & MDS & MDS & MMOBI \\
\hline
\end{tabular}

Table 6: The four communities logging most and least intensively, according to the size of the last ten-year plan logging area. Table shows other variables pertaining to management practices in these communities.

\section{Discussion}

\subsection{Land-use zoning}

A central focus of this thesis was to address the debate of land sharing vs. land sparing logging regarding forest conservation and utilization, by exploring management practices applied by community forests of Sierra Norte of Oaxaca. Sierra Norte exemplifies a case of forest utilization and community conservation by land sparing. Land sparing implies a zoning process, concentrating land uses into blocks. Land sharing 
suggests a non-zoning approach, where different land uses are scattered across the landscape.

My primary source for gathering land use data was the communities' Forest Management Plans (Programas de Manjo Forestal, PMF); these were ubiquitous in my study, all 23 communities in my data frame have PMFs. The PMFs set up a land-use zoning with clear divisions into forest areas and other areas. Then the forest areas are subdivided various ways including production, conservation, and restoration. This constitutes a land sparing approach; it is zoning agricultural and other uses in particular areas, and forest uses in others. In this case, however, land sparing does not imply that agriculture is all in one big block, it can also be scattered around (outside of forest areas). In any event, forest masses are in large, zoned blocks. Thus, PMFs carry out both a land sparing approach in zoning agriculture and forests, and a forest sparing logging approach by zoning the forest areas.

The PMFs are legally required, and the use of the production areas is legally regulated. These Plans are created by Foresters and supported by SEMARNAT, but before they can be implemented, they have to be formally approved by the communal assemblies. However, the land-use zoning is not written into community statutes and its conservation aspects are not officially considered "conservation" under Mexican protected areas law. For communities that have OTCs and have written rules around them, there is an extra layer of community regulation that could be called "communityregulated informality". However, PMFs are in their general land-use zoning widely accepted and known by the communities, even if they are not informally regulating them with an overlay of written community rules. 
Community governance clearly plays a large role in forest conservation in SNO. Much of the forested area in the region is under informal conservation; conservation is done at the community level, through the establishment of OTCs, the implementation of PMFs, and in some cases, as expressed by comisariados during interviews, communal statutes. All rules and regulations regarding the use, access, and conservation of communal lands are established and enforced by community members. Even in the cases with no formal statutes, following the work of Van Vleet (2013) in several communities of Sierra Norte, and my own formal and informal interviews with community members, there is reason to believe that these communities respect and follow these rules.

My main focus for this study was on the PMFs, which is where the land-use zoning data came from. Prior to collecting any data, I hypothesized that three main factors would influence the distribution of land use across communities and the volumes of timber they harvest: typology, the size of total territory, and population density. Statistical analysis showed no significant correlation between typology and total area, forested area, size of conservation or production areas, or between typology and the volumes of timber logged. The sample is, however, dominated by Type IV communities, with sawmills and other advanced processing facilities. Type IV communities are, in general, the ones with most forested areas, with largest conservation and production areas, as well as the ones logging the highest volumes of timber. Thus, it is of particular note that vertically integrated community logging enterprises are also the ones that are conserving the most territory. This supports the numerous arguments that, though responsible management of their forests, communities actively maintain forest cover and decrease degradation, thus reducing greenhouse gas emissions and enhancing forest 
carbon stocks (Bray et al. 2007, Chhatre and Agrawal 2009, Bray 2010, Bray and DuranMedina 2014, Stevens et al. 2014). Out of a total area of 201,093.94 hectares within the 23 communities in my study, there is a total of $156,550.63$ ha (about $78 \%$ ) forest cover; 18 of these communities boast over $70 \%$ forest cover.

Evidence shows universal land-use zoning is one of the elements that has led to high forest cover and zoned conservation areas, but with unpredictable relationships between those factors and other relevant variables. For example, the three communities with largest territories (Pueblos Mancomunados, Santa Catarina Ixtepeji, and Ixtlan de Juarez) also have the largest areas of forest; which may be expected. However, some of the smallest, as well as some of the largest community territories have all or almost all of their territory in forest cover: La Trinidad, Zona 1 El Carrizal, and San Mateo La Reforma, with $100 \%, 99 \%$, and $97 \%$ respectively, followed by Ixtlan de Juarez, with $96 \%$ of its large territory being forested. However, size does matter. In general, larger territories with larger forested areas were shown to have larger conservation and production areas, as well as higher volumes of timber logged.

Of the total forested area, $46 \%$ of the land is under exclusively informal conservation. There are no public protected areas in my study communities; all conservation is practiced at the community level. Santiago Comaltepec (86\%), Pueblos Mancomunados (74\%), and San Mateo La Reforma (69\%), are the communities with the most area under conservation. The size of conservation areas was most strongly influenced by the amount of forested areas, which means that the more forest the communities have, the more they conserve. There are exceptions here as well, San Juan Bautista Atepec and San Miguel Aloapam were two examples of outliers: large 
communities with large total and forested areas, but small conservation areas. This can be attributed to the fact that both have very large populations, which showed to be a more influential factor than size of territory or forested area. Much of the land in these communities is allocated to logging and agriculture.

Production areas account for $47 \%$ of the total forested land, although generally only a fraction of these areas is logged at one time. The size of production areas was most influenced by the size of the total area, which is strongly correlated with population more area is likely to mean more people, which means higher demand for resources as well as employment. The volumes of timber harvested were most influenced by the size of population, with the same reasoning as with production areas - more people, more demand for resources and employment, in addition to more laborers obtainable for the forestry sector. Population density, on the other hand, did not show a correlation with any of the variables except one: it showed a strong negative correlation with the size of conservation areas - more densely populated areas have smaller conservation areas. San Juan Bautista Atepec (86\%), Zona 2 El Carrizal (83\%), and San Andres Yatuni (80\%) were found to be the communities with the largest percentage of land allocated for production (these communities are the ones with the least conservation areas).

The size of the areas logged in the last ten-year plan (last harvest cycle, 20032013) and consequently the size of the remaining area (under "medium-term conservation") were most strongly (positively) correlated with and influenced by the size of total production area. In other words, larger production areas tend to offer communities an opportunity to satisfy their harvesting needs, while allowing them to conserve as well. 
An interesting find was the fact that these ten-year plan logging areas accounted for a small portion of the total production area. On average from 2003-2013, communities only logged on about $39 \%$ of the total land allocated for production, leaving over $60 \%$ of the land on type of fallow period, allowing for soil restoration and natural regeneration. If natural regeneration does not occur, communities will physically plant seedlings to reforest the area. That means that large fractions of the production areas are indirectly under what I refer to as "medium-term conservation". This medium-term conservation period may last from 40 to 60 years, depending on how long the harvest cycle is. Thus, Sierra Norte presents a dynamic landscape, on which logging occurs over 10-year periods, but where in any given time over that period, forests (even within production areas) are still being conserved, as recent logged areas may be left entirely to rest and regenerate for up to 60 years at a time. This provides further evidence of sustainable management practiced by forest communities.

\subsection{Timber Harvested 1993-2003 and 2003-2013}

It has been known, but not quantified or well documented, that large amounts of timber have come out of Sierra Norte in the last decades. By reviewing logging annual reports, I extrapolated 10-20 years of data for volumes of timber authorized and harvested from the periods of 1993 to 2003 and 2003 to 2013. For the most recent period, 20032013, I acquired data for 21 out of the 23 communities in my sample, and found that

during that communities were authorized to harvest $2,106,441.57 \mathrm{~m}^{3}$ of timber, and harvested a total of $1,482,210.07 \mathrm{~m}^{3}$ (about $70 \%$ consisting of Pinus species), or about $70 \%$ of the authorized volume. 
For the previous ten-year period, from 1993 to 2003, I only obtained data for 13 out of the 23 communities. I found that during that period, these 13 communities were authorized to harvest $1,925,067.10 \mathrm{~m}^{3}$, but only logged a total of $950,357.39 \mathrm{~m}^{3}$, or about $49 \%$ of authorized volumes (also consisting mainly of Pinus).

In the earliest ten years, the communities with the full 20 years of logging data harvested an average of $59 \%$ of the timber volumes they were authorized to $\log$. Assuming a similar percentage for the communities with missing data in the first ten years, this would suggest a harvested volume of $495,419.96 \mathrm{~m}^{3}$ for the missing communities. This would give an estimated volume harvested of $1,445,777.35 \mathrm{~m}^{3}$ for the first ten-year period (1993-2003), and a volume of 1,503,339.15 $\mathrm{m}^{3}$ from 2003-2013, thus proposing an estimated total volume harvested of $2,949,116.50 \mathrm{~m}^{3}$ for the full 20 years between the 22 communities with logging data. Estimates of timber volumes harvested at the regional scale in Sierra Norte had not been attempted.

The timber produced in Sierra Norte is a significant amount. Between 2003 and 2013, Oaxaca was among the five principal timber producers in Mexico, along with Durango, Chihuahua, Michoacán, and Veracruz. The country’s latest Anuário Estadítico de Produccion Forestal (2014) or the Annual Statistical Forest Production Report, which is generated by SEMARNAT, reported that Oaxaca produced $4,252,242 \mathrm{~m}^{3}$ of timber between 2002 and 2011. During that same 10 -year period, a volume of $1,495,891 \mathrm{~m}^{3}$ of timber was harvested by 21 of the logging SNO communities, accounting for over 1/3 of all of the state's timber production (35\%). 
Figure 16: Volumes of Timber Produced in Oaxaca and Sierra Norte 2002-2011

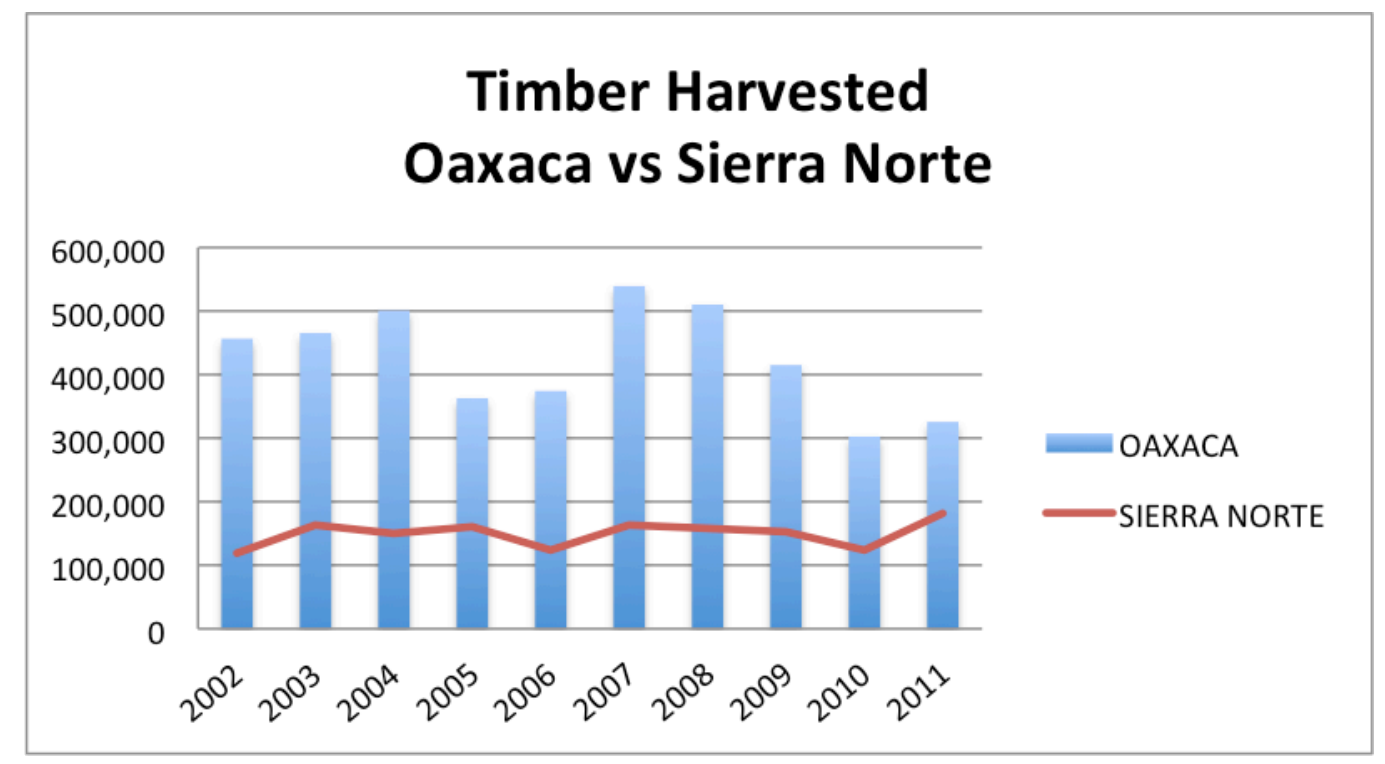

Figure 16: Volumes of timber harvested (m3) in the state of Oaxaca and in 21 logging communities of Sierra Norte from 2002 to 2011. Oaxaca data extrapolated from the Anuário Estadítico de Produccion Forestal (2014) and Sierra Norte from field notes (Logging Annual Reports).

During both periods (1993-2003 and 2003-2013), most communities consistently harvested below authorized volumes. Through interviews with the Foresters in charge of the creating management plans as well as with the Comisariados, I found that, although there was more than one reason for communities to under harvest, such as lack of laborers or resources, issues with access and lack of organization, or lack of efficiency, over half of them (10 out 19 responses) stated that they made the conscious decision to not harvest all the timber they were authorized to, in order to conserve their resources. This finding corroborates studies that have shown that, when given the authority and recognition of their customary rights over forests, communities limit their extractions of forest products and apply sustainable approaches to their management practices (Bray et 
al. 2003, Chhatre and Agrawal 2009, Bray 2010, Porter-Bolland et al. 2012, Stevens et al. 2014, Baraloto et al. 2014).

\subsection{Management Practices and Conservation}

There is a myriad of literature on the negative impacts of different types of selective logging, as well as more intensive practices, such as clear-cuts, on forests in the tropics and worldwide (Asner et al. 2009, Blaser et al. 2011, Shwartz 2005, Keenan et al. 1993, WWF 2016). However, Sierra Norte shows that both these practices and other logging practices can be done in a biodiversity-friendly manner, when carried out in a matrix of community-protected forests. This study found that an estimated 2,949,116.50 $\mathrm{m}^{3}$ of timber has come out of SNO in a period of 20 years, while the region still boasts almost $80 \%$ of forest cover. This timber was produced by application of selective logging, selection cuts, as well as small clear-cuts.

Although generally, any silvicultural practice may lead to negative impacts, it is possible to do it in a non-destructive manner, depending on who is doing it and how. In the case of this study, the way indigenous communities of Sierra Norte are doing it seems to be on the positive side, with a combination of both low and high intensity logging applied across the landscape.

Table 7, below, shows the five communities with the most forest cover, with the largest percentages of areas under permanent conservation and production, and the communities with the most timber harvested per hectare. It can be seen that neither applying a more "environmentally friendly" (MMOBI) nor a "more intensive" (MDS) 
logging method necessarily dictates forest conservation; it is all about properly tending for the land and resources before, during, and after each harvest.

Generally, communities applying a mix of both MMOBI and MDS have the most forest cover, the most areas under permanent conservation, and harvest the most timber per hectare. However, there are communities, with larger areas under production (Zona 2 El Carrizal for example, the second largest), solely applying the MMOBI method, as well as communities, like Santiago Comaltepec, with large areas under conservation, solely applying the more intensive MDS logging method. It is difficult to attribute conservation to silvicultural practices alone, since there are unrelated factors that may create conservation areas by default - for example, slopes greater than $100 \%$ or 45 degrees, areas over 3000 meter above sea level, and cloud forests automatically fit the criteria to be placed under conservation.

Table 7: Silvicultural Practices

\begin{tabular}{|c|c|c|c|}
\hline Most forest cover & $\begin{array}{c}\text { Most forest } \\
\text { cover (\%) }\end{array}$ & $\begin{array}{c}\text { Most conservation } \\
\text { area }\end{array}$ & $\begin{array}{c}\text { Most conservation } \\
\text { area (\%) }\end{array}$ \\
\hline $\begin{array}{c}\text { La Trinidad } \\
\text { (MMOBI \& MDS) }\end{array}$ & $100 \%$ & $\begin{array}{c}\text { Santiago } \\
\text { Comaltepec (MDS) }\end{array}$ & $86 \%$ \\
\hline $\begin{array}{c}\text { Zona 1 El Carrizal } \\
\text { (MMOBI \& MDS) }\end{array}$ & $99 \%$ & $\begin{array}{c}\text { San Mateo La } \\
\text { Reforma (MMOBI) }\end{array}$ & $69 \%$ \\
\hline $\begin{array}{c}\text { San Mateo La } \\
\text { Reforma } \\
\text { (MMOBI) }\end{array}$ & $97 \%$ & $\begin{array}{c}\text { San Juan Luvina } \\
\text { (MMOBI \& MDS) }\end{array}$ & $64 \%$ \\
\hline $\begin{array}{c}\text { (xtlan de Juarez } \\
\text { (MMOBI \& MDS) }\end{array}$ & $96 \%$ & $\begin{array}{c}\text { Ixtlan de Juarez } \\
\text { (MMOBI \& MDS) }\end{array}$ & $60 \%$ \\
\hline $\begin{array}{c}\text { San Martin } \\
\text { Buenavista (MDS) }\end{array}$ & $96 \%$ & $\begin{array}{c}\text { Zona 1 El Carrizal } \\
\text { (MMOBI \& MDS) }\end{array}$ & $56 \%$ \\
\hline
\end{tabular}




\begin{tabular}{|c|c|c|c|}
\hline $\begin{array}{c}\text { Most production } \\
\text { area }\end{array}$ & $\begin{array}{c}\text { Most production } \\
\text { area (\%) }\end{array}$ & $\begin{array}{c}\text { Timber } \\
\text { volumes/hectare }\end{array}$ & $\begin{array}{c}\text { Timber } \\
\text { volumes/hectare } \\
\text { (m3/ha) }\end{array}$ \\
\hline $\begin{array}{c}\text { San Juan Bautista } \\
\text { Atepec (MMOBI } \\
\text { \& MDS) }\end{array}$ & $86 \%$ & $\begin{array}{c}\text { Ixtlan de Juarez } \\
\text { (MMOBI \& MDS) }\end{array}$ & 115.98 \\
\hline $\begin{array}{c}\text { Zona 2 El Carrizal } \\
\text { (MMOBI) }\end{array}$ & $83 \%$ & $\begin{array}{c}\text { San Martin } \\
\text { Buenavista (MDS) }\end{array}$ & 82.26 \\
\hline $\begin{array}{c}\text { San Andres Yatuni } \\
\text { (MDS) }\end{array}$ & $80 \%$ & $\begin{array}{c}\text { La Trinidad } \\
\text { (MMOBI \& MDS) }\end{array}$ & 80.00 \\
\hline $\begin{array}{c}\text { Capulalpam de } \\
\text { Mendez (MDS) }\end{array}$ & $76 \%$ & $\begin{array}{c}\text { San Andres Yatuni } \\
\text { (MDS) }\end{array}$ & 68.11 \\
\hline $\begin{array}{c}\text { La Trinidad (MDS } \\
\text { Y MMOBI) }\end{array}$ & $74 \%$ & $\begin{array}{c}\text { Santa Maria Nieves } \\
\text { (MDS) }\end{array}$ & 61.08 \\
\hline
\end{tabular}

Table 7: The five communities with the most forest cover, with the largest percentages of conservation and production areas, and the communities with the most timber harvested per hectare.

To measure the intensity of logging applied to the ten-year logging areas of each community, I found how much timber was being produced per hectare within the logging area for the last ten-year period (area being logged on that ten-year plan, 2003-2013, not the total production area), then the intensity was determined by dividing the area logged by the volume harvested during that period. In order to focus on specifics, I will discuss the case of the four communities presented in Table 6 earlier, as the communities practicing the most and the least intensive logging in their forests.

Both communities logging most intensively are applying an MDS-like silvicultural method (Sistema de Manejo Sostenible de Pueblos de Oaxaca de Jica), and the two logging least intensively are applying MDS and MMOBI. As previously stated, MMOBI is the silvicultural method considered to be the more environmentally friendly, which uses selective cuts; MDS is considered a more intensive practice, as it does apply some forms of strip clear-cuts. 
San Martin Buenavista (BV) and Santa Maria Nieves are the communities with the smallest ten-year plan logging areas (116.33 ha and 123.33 ha, respectively); yet, they are the ones harvesting the most timber by volume per hectare $\left(82 \mathrm{~m}^{3} /\right.$ ha and 61.08 $\mathrm{m}^{3} / \mathrm{ha}$ ). From these small logging areas, these communities harvested $99 \%(\mathrm{BV})$ and $95 \%$ (Nieves) of the timber volumes they were authorized to log, while only logging on $5 \%$ and $25 \%$ of their total production areas. This means that, while neither of them has a very large area under permanent conservation (43\% and 30\%, respectively), within their production areas, there is $95 \%(\mathrm{BV})$ and $75 \%$ (Nieves) of forest left untouched, under medium-term conservation. Logging turns (turnos) in both of these communities are of 60 years (six 10-year harvest cycles), meaning only a particular annual stand is logged every 10 -year cycle for every 60 years, leaving the largest part of the production forest in recovery from logging for long periods of time. The production area in Buenavista occupies 2,148.50 ha of the total forested territory and Nieves' 500.82 ha. Collectively, within their production area alone, there will be $2,416.69$ ha of forest left under this "medium-term conservation". In addition to PMFs. both Buenavista and Nieves have OTCs, a complementary layer of community rules that reinforce the PMFs. These cases perfectly exemplify the concept of land sparing, where by intensively logging in a concentrated small area, more forestland is allowed to be spared for conservation, even if for a medium-term.

Although communities with larger production areas tend to have smaller areas under conservation, results show that large portions of the forest are still being conserved for long periods of time within production areas. Thus, between areas under permanent and under medium-term conservation, a total of about $75 \%$ of the total forest area across 
all communities are under some form of conservation at a given time between logging cycles. This provides further evidence of sustainable management practiced by forest communities.

San Miguel Aloapam is the community practicing the least intensive logging, harvesting $47 \mathrm{~m}^{3} / \mathrm{ha}$, within a large logging area of 4,172.20 ha, which accounts for $52 \%$ of the total production area. Aloapam also applies the MDS method in its silvicultural practices. Two things stand out in this case: although the more intensive silvicultural practice is being applied, the extent of the logging area permits that the practice be distributed across the landscape, causing less of an impact; and that in spite of being a large community, with large total and forested areas, it only has $18 \%$ of its forests under permanent conservation areas. This may be attributed to the fact that both have very large populations; much of the land in these communities is allocated to both logging and agriculture. Aloapam also has a logging turno of 60 years, and almost half of its production area, which is $8,033.04$ ha, is under medium-term conservation, as well as 1,404.08 ha under restoration (these are non-commercial forests and forests of low productivity).

Teococuilco de Marcos Perez applies the less intensive method, MMOBI (selection cuts). In the last ten-year plan, the community logged $29.52 \mathrm{~m}^{3} /$ ha, over an area of $2,228.16$ ha ( $48 \%$ of the total production area). They only harvested $51 \%$ of the timber authorized as a collective conscious conservation decision, as per the community's Forester. Over 1/3 of their forested areas are under permanent conservation $(2,736.21 \mathrm{ha})$ and over half of the production area is under medium-term conservation, for a turno of 50 years. 
Results suggest that the size of the area being logged area or even the silvicultural practices do not necessarily influence the volumes of timber produced and harvested. Either way, sustainable practices appear to be applied, although there are some trade-offs. The MMOBI method allow for more predictable development over the long term. Regeneration cuttings facilitate uneven-aged management and promoting restoration. However, the practice does not contribute to the regeneration of pine. The MDS method addresses the deficiencies of MMOBI for pine management. MDS is characterized by a series of cuts in the logging cycle that may include some strip clear-cutting, traditionally in blocks of about one hectare, or sometimes in larger patches of two or three hectares. This method, although more intensive, still reduces logging impacts in other forms, in terms of skidding, concentrating the effects of logging in a smaller area, and promoting natural regeneration.

In areas where higher intensity logging occurs, extraction is happening is smaller zones, thus reducing the impacted area, while producing high yields of timber. In areas where low intensity logging occurs, even though pine regeneration may not be very strong where MMOBI is applied, impacts of logging in the overall affected area are reduced, while timber is still coming out of relatively small areas. Between 2003 and 2013, in 21 logging SNO communities, 1,503,339.15 $\mathrm{m}^{3}$ of timber came out of a total of $28,113.04$ hectares of logged area, with an overall logging intensity of $53 \mathrm{~m}^{3} / \mathrm{ha}$. This timber was harvested from a production area with the capability of supplying timber volumes of about $250 \mathrm{~m}^{3} / \mathrm{ha}$ (being able to produce volumes higher than $150 \mathrm{~m}^{3} / \mathrm{ha}$ is a criterium used to designate production areas). 
Moreover, regardless of the silvicultural methods practiced, all of the logging communities in SNO follow certain conservation standards in their management plans. In areas where natural regeneration does not occur after a harvesting cycle, they plant from 1,111 to 2,500 trees per hectare, depending on the size of the logging area. They implement fire prevention by building brechas cortafuego, or firebreaks, which means the removal of plant material up to the mineral soil in a forested area, so that a wildfire is eliminated by not being allowed to spread to other trees. Areas that are affected by wildfires are reforested. Soil erosion is prevented with the implementation of curvas de nivel, or skid trail curves, which are temporary "roads" or pathways used to move logs and trees from the woods. This technique minimizes disturbance to the soil such as surface runoff and leeching into waterbodies. Manantiales, or water springs, their source of water, are always within community-protected areas, as to not get contaminated.

Flora and fauna protection measures are implemented as well. These include building small, medium and large sized madrigueras, or fauna burrows/huts, for squirrels, raccoons, foxes, porcupines, and even pumas, with the residual woods from harvest; translocation of plants, such as bromeliads and orchids, found in lower logging zones to higher, more humid areas, outside of logging zones; restricting areas where any threatened species is found (even if it is within a logging area). In addition, hunting is strictly prohibited. In all communities, directional felling is performed, which is a cutting method where one can determine the direction in which the tree will fall, reducing the risk of affecting other tress by accident. Nine of the 23 communities (almost $40 \%$ ) are either actively certified under the Forest Stewardship Council (FSC) or in the process of 
getting certified, which is a voluntary program that sets standards for responsible forest management.

Supplementary conservation practices are also applied across the region, even within logging activities. As an example, several communities incorporate "best practices of forest management for biodiversity conservation" in their management plans. The purpose of these practices is to assist foresters and forest managers alike in applying silvicultural methods that improve conditions for biodiversity. "Best practices" are intended to aid in identifying, understanding, and implementing management approaches for biodiversity conservation while production achieves the objectives set in their management plans. There are two main parts to this approach: the first presents the necessary framework to implement best practices, while the second is presented at three levels - landscape, stand, and site.

Understanding the relationships between management practices and the needs of different species is of utmost importance, especially when species require special habitats or particular environmental conditions in order to complete their lifecycle (Larreta 2013). In order to conserve species and their habitats in managed forests, it is necessary to know the specific characteristics of the forest (e.g., from the landscape level to the composition and structure of the stand and site) to maintain the functionality of the natural habitat, and in $\mathrm{SNO}$, communities are working to achieve that.

\section{Conclusion}

The land sharing/sparing debate is a popular concept today among land and forest managers worldwide. With the increasing demand for forest goods and services, finding a 
way to reconcile forest utilization and conservation is paramount for the preservation of our natural world. In this study, I aimed to use the notion of land sparing in the context of community conservation and management, in particular for timber production, to showcase an area where land sparing conservation has been happening for a long time, through community land-use zoning and well managed production of timber, in the Sierra Norte of Oaxaca (SNO), Mexico.

Some of the overall questions I set out to answer were about the degree in which forest communities of SNO are conserving forests, while also carrying out timber production, and the percentages of the forest that are being logged and being conserved. I found that, across 23 logging communities, which amounted to 201,093.94 hectares, of which $78 \%$ is forested $(156,550.63 \mathrm{ha}), 47 \%$ of the forest is under management for timber production, and $46 \%$ is under permanent community conservation while. Within the production areas, about $61 \%$ of the forest (accounting for $29 \%$ of total forested area), might be under "medium-term conservation" in between harvest cycles sometimes for up to 60 years. Thus, between areas under permanent and under medium-term conservation, a total of about $75 \%$ of the total forest area across all communities are under some form of conservation at a given time between logging cycles. This provides further evidence of sustainable management practiced by forest communities.

I also aimed to assess the implications of silvicultural practices applied in SNO for timber production and forest conservation. My concluding results are that there will always be some trade-offs between production and conservation, but if management is done appropriately, deforestation and forest degradation can always be prevented. It is difficult to attribute conservation to a specific source, since there are various factors to be 
considered: silvicultural practices, areas under permanent conservation, areas under medium-term conservation, logging intensity, volumes (and percentages) of timber harvested, as well as social variables such as reasons for under harvesting, population density and community involvement. Further research is necessary to evaluate each of the factors individually to determine what would have the most influence on conservation. As a whole, all of these contribute to conservation.

In areas where higher intensity logging occurs, extraction is happening in smaller zones, thus reducing the impacted area, while producing high yields of timber. In areas where low intensity logging occurs (even though pine regeneration may not be very strong where MMOBI is applied), the impacts of logging are reduced in the overall affected area, while significant amounts of timber are still being produced. Either way the impacts of logging are minimized. Between 2003 and 2013, in 21 logging SNO communities, $1,503,339.15 \mathrm{~m}^{3}$ of timber came out of a total of $28,113.04$ hectares of logged area (amounting to $53.47 \mathrm{~m}^{3} /$ ha overall). This area is only about $39 \%$ of the total production area, suggesting that a high yield of timber was harvested from even smaller areas than the total land allocated for production, further reducing the impacts of logging and conserving forest cover.

In addition, I sought to quantify the timber that has been removed from SNO in the last 20 years and found that an estimated $2,949,116.50 \mathrm{~m}^{3}$ of timber were harvested, while the region still displays almost $80 \%$ forest cover. During a 10 -year period, from 2002 to $2011,1,495,891 \mathrm{~m}^{3}$ of timber was harvested by 21 of the logging SNO communities, accounting for over $1 / 3$ of all of the timber production in the state of Oaxaca (35\%). 
Finally, I found that the communities of SNO have been conserving their forests through the zoning of different land-use types, allocating forest areas for a variety of forms of conservation and protection, for timber production, and for other uses, such as agriculture and pasture. Reforestation is always performed if natural regeneration does not occur after harvest, and in areas affected by wildfires; fire is prevented by the implementation of firebreaks; soil erosion is prevented with the construction of skid trail curves; springs, creeks and streams are always within community-protected areas; flora and fauna protection are implemented by building fauna burrows/huts with residual woods from harvest; plants such as bromeliads and orchids are translocated from logging zones to more humid areas; areas (even within logging zones) become restricted if any threatened species is identified; "best practices of forest management for biodiversity conservation" are applied as part of their management plans; directional felling is performed; and most communities consciously log below authorized timber volumes to conserve natural resources.

My concluding results are that, in the Sierra Norte, a region with no public protected areas, indigenous communities have been actively conserving their forests for decades, through conservation zoning, a land sparing approach, and careful management of their logging areas. Forest Management Plans (i.e., PMFs) and Land-use zoning Plans (i.e., OTCs) are the instruments used for these zoning practices. However, community governance plays a major role, as rules and regulations regarding the use, access, and conservation of communal lands are established and enforced by community members. SNO communities seem to have developed a culture of conservation that comes from years of traditions and a close relationship with their forests and the natural world. The 
findings of this study support numerous arguments that advocate for community forest management, as forest communities have proven to maintain forest cover and decrease degradation, thus reducing greenhouse gas emissions and enhancing forest carbon stocks.

\section{Literature Cited}

Agraria, L. (1993). Ley Agraria de 1992. México, Sista.

Agrawal, A. (2007). Forests, governance, and sustainability: Common property theory and its contributions. International Journal of the Commons, 1(1), 111-136.

Aldrich, M., Billington, C., Edwards, M., \& Laidlaw, R. (1997). Tropical montane cloud forests: An urgent priority for conservation World Conservation Monitoring Centre.

Alix-Garcia, Jennifer; de Janvry, Alain; and Sadoulet, E. (2003). A Tale of Two Communities: Explaining deforestation in Mexico. Department of Agricultural and Resource Economics, UC Berkeley.

Alix-Garcia, J.; Aronson, G.; Radeloff, V.; Ramirez-Reys, C.; Shapiro, E.; Sims, K.; Yanez-Pagans, P. (2014). Environmental and Socioeconomic Impacts of Mexico's Payments for Ecosystem Services Program Grantee Final Report, 1-100.

Angelsen, A., Jagger, P., Babigumira, R., Belcher, B., Hogarth, N. J., Bauch, S., ... \& Wunder, S. (2014). Environmental income and rural livelihoods: a globalcomparative analysis. World Development, 64, S12-S28.

Antinori, C., \& Bray, D. B. (2005). Community forest enterprises as entrepreneurial firms: Economic and institutional perspectives from Mexico. World Development, 33(9), 1529-1543.

Arriaga, L. (2000). Regiones terrestres prioritarias de méxico Comisión Nacional para el Conocimiento y Uso de la Biodiversidad. 
Asbjornsen, H., \& Ashton, M. S. (2002). Perspectives on Community- Based Forest Management in Oaxaca, Mexico. Journal of Sustainable Forestry, 15 (February 2015), 127-131. doi:10.1300/J091v15n01

Asner, G. P., Rudel, T. K., Aide, T. M., Defries, R., \& Emerson, R. (2009). A contemporary assessment of change in humid tropical forests. Conservation Biology, 23(6), 1386-1395.

Baraloto, C., P. Alverga, S. Baéz Quispe, G. Barnes, N. Bejar Chura, I. Brasil da Silva, W. Castro, H. Da Souza, I. De Souza Moll, J. Del Alcazar Chilo, H. Duenas Linares, J. Garate Quispe, D. Kenji, H. Medeiros, C. A. Rockwell, A. Shenkin, M. Silveira, J. Southworth, G. Vasquez, and S. Perz. (2014). Trade-offs among forest value components in community forests of southwestern Amazonia. Ecology and Society 19(4): 56.

Barry, D., Bray, D., Madrid, S., Merino, L., \& Zuñiga, I. (2010). Sustainable forest management as a strategy to combat climate change: lessons from Mexican communities, Rights and Resources 45. Retrieved from http://www.rightsandresources.org/documents/files/doc_2018.pdflnhttp://www.righ tsandresources.org/es

Bernard, H. Russel. (2002). Research methods in anthropology: Qualitative and Quantitative Approaches Altamira press.

Biggs, R., Schlüter, M., Biggs, D., Bohensky, E. L., BurnSilver, S., Cundill, G., ... \& Leitch, A. M. (2012). Toward principles for enhancing the resilience of ecosystem services. Annual Review of Environment and Resources, 37, 421-448.

Blaser J, Sarre A, Poore D, Johnson S. (2011). Status of tropical forest management 2011. Technical Series 38. International Tropical Timber Organization.

Bojorquez, L. (2000). Background environmental analysis for the GEF Integrated Ecosystems Management Project (CONIBIO). Cited in World Bank Project Appraisal Document, June. Mimeo.

Borrini-Feyerabend, G. 1997. Beyond fences: Seeking social sustainability in conservation. Gland, Switzerland: World Conservation Union (IUCN). 
Borrini-Feyerabend, G., Banuri, T., Farvar, T., Miller, K., \& Phillips, A. (2002). Indigenous and local communities and protected areas: Rethinking the relationship. Parks, 12(2), 5-15.

Brandon, K., Gorenflo L. J., Rodrigues, A. S. L., \& Waller, R. W. (2005). Reconciling biodiversity conservation, people, protected areas, and agricultural suitability in Mexico. World Development, 33 (9), 1403-1418. doi: 10.1016/j.worlddev.2004.10.005

Bray, D. B. (1991). The struggle for the forest: Conservation and development in the Sierra Juarez. Grassroots Development, 15, 3.

Bray, D.B., Merino-Perez, L., Negreros-Castillo, P., Holtz, G., Torres-Rojo, J.M., Vester, H.F.M. (2003). Mexico's Community-managed Forests as a Global Model for Sustainable Landscapes. Conservation Biology 17, 672-677.

Bray, D., Ellis, E., Armijo-Canto, N., \& Beck, C. (2004). The institutional drivers of sustainable landscapes: A case study of the 'Mayan Zone' in Quintana Roo, Mexico. Land Use Policy, 333-346.

Bray, D. B., Antinori, C., \& Torres-Rojo, J. M. (2005). The Mexican model of community forest management: The role of agrarian policy, forest policy and entrepreneurial organization. Forest Policy and Economics, 8(4), 470-484.

Bray, D., Duran Medina, E., Merino Perez, L., \& Torres Rojo, J. (2007). Nueva evidencia: Los bosques comunitarios de Mexico. Informe De Investigaciones, Agrupacion Sierra Madre, S.C. (Folleto Forestal).

Bray, D., Duran, E., \& Ramos, V. (2008). Tropical Deforestation, Community Forests, and Protected Areas in the Mayan Forest. Ecology and Society, 13(2), 56-73.

Bray, D. (2010). Info Brief, Toward 'post-REDD landscapes' Mexico's community forest enterprises provide a proven pathway to reduce emissions from deforestation and forest degradation. Retrieved from www.cifor.cgiar.org

Bray, D. \& Merino-Perez, L (2012) The Rise of Community Forestry in Mexico- History, Concepts, and Lessons Learned from Twenty-Five Years of Community Timber Production. 
Bray, D., \& Duran-Medina, E. (2014). Options for Reducing Carbon Emissions in Forest Management in the Oaxaca and Chihuahua Áreas de Acción Temprana REDD+. Alianza México Para La Reducción De Emissiones Por Deforestación Y Degradación.

Bruner, A., Gullison, R., Rice, R., \& Da Fonseca, G. (2001). Effectiveness of Parks in Protecting Tropical Biodiversity. Science, 125-128.

Butler, R. (2011). Fighting illegal logging in Indonesia by giving communities a stake in forest management. Mongabay.

CBD (2013). Convention on Biological Diversity. Mexico - Overview. Retrieved from http://www.cbd.int/countries/?country=mx

Chhatre, A., \& Agrawal, A. (2009). Trade-Off and Synergies Between Carbon Storage and Livelihood Benefits From Forest Commons. PNAS - Sustainability Science, 106(42), 17667-17670.

CONAFOR (2010). Vision de Mexico sobre REDD+ (1st ed., Rep. No. 1).

CONAFOR (2014). Readiness Preparation Proposal (R-PP) Template. Forest Carbon Partnership Facility, SEMARNAT-CONAFOR.

De Jong, I. Ricalde y A. Ordoñez (2004). Consolidación de la Oficina Mexicana para la Mitigación de Gases de Efecto

Deininger, K., \& Minten, B. (1999). Poverty, Policies, and Deforestation: The Case of Mexico. Economic Development and Cultural Change, 47(2), 313-344. doi:1. Retrieved from http://www.jstor.org/stable/10.1086/452403 doi:1

Del Gatto, Filippo (2013). Community Forestry in Honduras: A Path towards Better Governance. Forest Trends. Issue brief No. 8

Edwards, David P., James J. Gilroy, Paul Woodcock, Felicity A. Edwards, Trond H. Larsen, David JR Andrews, Mia A. Derhé et al (2014). "Land-sharing versus landsparing logging: reconciling timber extraction with biodiversity conservation." Global change biology 20, no.183-191. 
Ellis, E. a., \& Porter-Bolland, L. (2008). Is community-based forest management more effective than protected areas?. A comparison of land use/land cover change in two neighboring study areas of the Central Yucatan Peninsula, Mexico. Forest Ecology and Management, 256, 1971-1983.

FAO (2010a), Global Forest Resources Assessment, 2010-Main report. FAO Forestry Paper 163. Rome, Italy.

FAO (2010b), Global Forest Resources Assessment, 2010-National Report, Mexico

Figueroa, F., \& Sánchez-Cordero, V. (2008). Effectiveness of natural protected areas to prevent land use and land cover change in Mexico. Biodiversity and Conservation Biodiversity Conservation (17), 3223-3240

Figueroa, F., \& Sánchez-Cordero, V. (2008). Effectiveness of natural protected areas to prevent land use and land cover change in Mexico. Biodiversity and Conservation, 17(13), 3223-3240.

Fonseca, Salvador Anta (2005). "Forest Management in the Community of Santa Catarina Ixpeji, Oaxaca, Mexico". CCMSS. The Rights and Resources Initiative.

Fonseca, S. A. (2006). Ordenamiento territorial comunitario: un debate de la sociedad civil hacia la construcción de políticas públicas. Instituto Nacional de Ecología.

Fox, Jonathan (n.d.) Mexico's Indigenous Population. Cultutal Survival. https://www.culturalsurvival.org/ourpublications/csq/article/mexicos-indigenouspopulation

FSC (2016). Public Certificate Search: Forest Stewardship Council International. Retrieved from http://info.fsc.org/certificate.php

FSS (2010). Florida Forest Stewardship. University if Florida, IFAS Extension. Unevenaged Management - A "Natural" Approach. Retrieved from http://www.sfrc.ufl.edu/extension/florida_forestry_information/forest_management/ uneven_aged_management.html

Gibson, L., Lee, M.L., Koh, L.P. (2011) Primary forests are irreplaceable for sustaining tropical biodiversity. Nature 478, 378-381. 
Getzner, M., Jungmeier, M., \& Pfleger, B. (2012). Evaluating Management Effectiveness of National Parks as a Contribution to Good Governance and Social Learning. INTECH Open Access Publisher.

Gómez-Mendoza, L., Vega-Peña, E., Ramírez, M., Palacio-Prieto, J., \& Galicia, L. (2006). Projecting land-use change processes in the Sierra Norte of Oaxaca, Mexico. Applied Geography, 276-290.

Hegde, R., Suryaprakash, D., Achoth, D., \& Bawa, D. S. (1996). Extraction of nontimber forest products in the forests of Biligiri Rangan Hills, India. 1. Contribution to rural income. Economic Botany, 50(3), 243-251.

Hernández-Díaz, J. C., Rivas, J. C., Quiñones-Chávez, A., Bacon-Sobbe, J. R., \& VargasLarreta, B. (2008). Evaluación del manejo forestal regular e irregular en bosques de la Sierra Madre Occidental. Madera y bosques, 14(3), 25-41.

Honey-Rosés, Jordi (2009) Illegal Logging in Common Property Forests, Society \& Natural Resources: An International Journal, 22:10, 916-930

Howlader, A., \& Ando, A. W. (2016). Consequences of Protected Areas for Forest Extraction and Human Well-being: Evidence from Nepal. In 2016 Annual Meeting, July 31-August 2, 2016, Boston, Massachusetts (No. 236272). Agricultural and Applied Economics Association.

IISD (2014). International Institute for Sustainable Development. Retrieved from http://www.iisd.org/

INECC (2013). Intituto Nacional de Ecologia y Cambio Climatico, Mexico: Inventario de Emisiones de Gases de Efecto Invernadero. Retrieved from http://www.inecc.gob.mx/cpcc-lineas/597-cpcc-inventario

Keenan, R. J., \& Kimmins, J. P. (1993). The ecological effects of clearcutting. Environmental Reviews, 1(2), 121-144.

Lambrick, F. H., Brown, N. D., Lawrence, A., \& Bebber, D. P. (2014). Effectiveness of Community Forestry in Prey Long Forest, Cambodia. Conservation Biology, 28(2), 372-381.

Larreta, B. V. (2013). Manual de mejores practicas de manejo forestal para la conservacion de la biodiversidad. Mexico, CONAFOR. 
Laurance, W. F., Goosem, M., \& Laurance, S. G. (2009). Impacts of roads and linear clearings on tropical forests. Trends in Ecology \& Evolution,24 (12), 659-669.

Macqueen, D. (2007). Cutting edge: how community forest enterprises lead the way on poverty reduction and avoided deforestation. IIED Sustainable Development Opinion.

Madrid, L., Nuñez, J., Quiroz, G., \& Rodriguez, Y. (2009). La propiedad social forestal en México. Investigacion Ambiental, 1(2), 179-196.

Masera, O. and C. Sheinmaum. (2004). Mitigation de emisiones de carbono y prioridades de desarrollo nacional. In Cambio Climatico: Una Visión desde Mexico. A. Fernandez, J. Martinez, and P. Osnaya, eds. Mexico: INE SEMARNAT

McNeely, J. A., and S. J. Scherr. 2003. Ecoagriculture: Strategies to feed the world and save biodiversity. Future Harvest and IUCN. Washington, D.C.: Island Press.

Molnar, Augusta; Scherr Sara; Khare, Arvind (2004). Who conserves the world's forests? A new assessment of conservation and investment trends. Forest Trends \& Ecoagriculture Partners ISBN 1-932928-05-7

Naughton-Treves, L., Holland, M. B., \& Brandon, K. (2005). The role of protected areas in conserving biodiversity and sustaining local livelihoods. Annu.Rev.Environ.Resour., 30, 219-252.

Nepstad, D., Azevedo-Ramos, C., Lima, E., Mcgrath, D., Pereira, C., \& Merry, F. (2004). Managing the Amazon Timber Industry. Conservation Biology, 18(2), 575-577.

Nepstad, D., Schwartzman, S., Bamberger, B., Santilli, M., Ray, D., Schlesinger, P., . . . Rolla, A. (2006). Inhibition of Amazon Deforestation and Fire by Parks and Indigenous Lands. Conservation Biology, 20(1), 65-73.

OHCHR (2011) Office of the High Commissioner for Human Rights: Advancing Indigenous Peoples' Rights in Mexico.

Ostrom, E. (1990). Governing the commons: The evolution of institutions for collective action Cambridge University Press.

Pace, M. L., Carpenter, S. R., \& Cole, J. J. (2015). With and without warning: managing ecosystems in a changing world. Frontiers in Ecology and the Environment, 13(9), 460-467. 
Phalan, B., Onial, M., Balmford, A., \& Green, R. E. (2011). Reconciling food production and biodiversity conservation: land sharing and land sparing compared. Science, $333(6047), 1289-1291$.

Pollen, C., A. E., \& S. Z. (2015). Indigenous Life Plans And Carbon Finance: Two Sides Of The Same Coin? [Ecosystem Marketplace: A Forest Trend Initiative]. Retrieved from http://www.ecosystemmarketplace.com/articles/indigenous-life-plans-carbonfinance-two-sides-coin/

Porter-Bolland, L., Ellis, E. a., Guariguata, M. R., Ruiz-Mallén, I., Negrete-Yankelevich, S., \& Reyes-García, V. (2012). Community managed forests and forest protected areas: An assessment of their conservation effectiveness across the tropics. Forest Ecology and Management, 268, 6-17.

Putz, F. E., Sist, P., Fredericksen, T., \& Dykstra, D. (2008). Reduced-impact logging: challenges and opportunities. Forest ecology and management,256(7), 1427-1

Putz, F. E., Zuidema, P. A., Synnott, T., Peña-Claros, M., Pinard, M. A., Sheil, D. \& Palmer, J. (2012a). Sustaining conservation values in selectively logged tropical forests: the attained and the attainable. Conservation Letters,5 (4), 296-303.

Putz, F. E., Zu Getzner, M., Jungmeier, M., \& Pfleger, B. (2012b). Evaluating Management Effectiveness of National Parks as a Contribution to Good Governance and Social Learning. Protected Area Management, 129-148.

Ragin, C. C., \& Amoroso, L. M. (2010). Constructing social research: The unity and diversity of method Sage Publications, Incorporated.

Robson, J. P. (2007). Local approaches to biodiversity conservation: lessons from Oaxaca, southern Mexico. International Journal of Sustainable Development, $10(3), 267-286$.

Robson, J. P. (2011). The impact of rural to urban migration on forest commons in Oaxaca, Mexico.

Robson, J. P., and Berkes, F. (2011). Exploring some of the myths of land use change: Can rural to urban migration drive declines in biodiversity?. Global environmental change, 21(3), 844-854.

SEMARNAT. (n.d.) Ecosystem Services and Climate Change. General Coordination for Production and Productivity. Gobierno Federal. 
SEMARNAT (2008). Diario Oficial. NORMA Oficial Mexicana NOM-152SEMARNAT-2006

SEMARNAT (2009). Programa Especial de Cambio Climático 2009-2012. Mexico.

SEMARNAT (2014). Anuario de Producion Forestal 2013 (1st ed., Vol. 1, Tech. No. 1). Delegacion Tlalpan, Mexico, DF: D.R. (C) Secretaría de Medio Ambiente y Recursos Naturales.

Shwartz, M. (2005). Stanford Report. Selective Logging. The Carnegie Institution of Washington. Retrieved from http://news.stanford.edu/news/2005/october26/select102605.html

Stevens, C., Winterbottom, R., Springer, J., \& Reytar, K. (2014). Securing Rights, Combating Climate Change, World Resources Institute.

Sunderlin, W., Angelsen, A., Belcher, B., Burgers, P., Nasi, R., Santoso, L., \& Wunder, S. (2005). Livelihoods, Forests, And Conservation In Developing Countries: An Overview. World Development, 1383-1402.

Swanson, Timothy M. (1998). The economics and ecology of biodiversity decline: the forces driving global change. Cambridge University Press.

Van Vleet, E. (2013). From Passive to Active Community Conservation: A Study of Forest Governance in a Region of the Sierra Norte of Oaxaca, Mexico.

Van Vleet, Eric, Bray, David, \& Duran, Elvira (2016). Knowing but not knowing: Systematic Conservation Planning and Community Conservation in the Sierra Norte of Oaxaca. Manuscript submitted for publication in Land Use Policy

Vedeld, P., Angelsen, A., Bojö, J., Sjaastad, E., \& Berg, G. K. (2007). Forest environmental incomes and the rural poor. Forest Policy and Economics, 9(7), 869879.

Vosti, S. A., and Reardon, T. A. (2007). Sustainability, growth, and poverty alleviation: A policy and agroecological perspective. Intl Food Policy Res Inst. 
Walker, W., Baccini, A., Schwartzman, S., Ríos, S., Oliveira-Miranda, M. A., Augusto, C., \& Meyer, C. (2014). Forest carbon in Amazonia: The unrecognized contribution of indigenous territories and protected natural areas. Carbon Management, 5(5-6), 479-485.

World Bank (2014). Mexico Data. Retrieved from http://data.worldbank.org/country/mexico

World Resource Institute (2014). Community Forests: An Undervalued Approach to Climate Change Mitigation. http://www.wri.org

WWF (2016). World Wildlife Foundation Retrieved from http://www.worldwildlife.org/industries/timber

Zarin, D., Alavalapati, J., Putz, F., \& Schmink, M. (2004). Working Forests in the Neotropics: Conservation through Sustainable Management? Columbia University Press. Retrieved from http://www.jstor.org/stable/10.7312/zari12906

Zielke, K., Bancroft, B., \& Scott, M. (1999). Introduction to silvicultural systems. Victoria, BC: BC Ministry of Forests, Forest Practices Branch. 


\section{APPENDIX I:}

Translated questions from Interview with Foresters

\section{General Info}

1) Since when have you been the forest engineer to this community?

2) If you haven't been the engineer for the last 20 years, do you have the data on authorized and logged volumes for years 1993-2013? If not, do you know who the engineer was and his/her contact information?

3) When was the Forest Management Plan (FMP) first implemented in this community?

4) Can you confirm the CONAFOR Typology (I, II, III, IV) and specify the types of equipment used?

\section{Forest Management Plan}

5) Could you describe the method you use to determine the land use classification?

6) Can you comment, in particular, how the conservation areas are determined?

7) In The FMP, what exactly do "Restricted Areas" mean? How are those determined?

8) How exactly do the classifications "Protection of Habitats" and "Forest Protection" differ?

9) What's the difference between "Areas to Intervene" and "Areas to Utilize"?

10) What's the difference between "Low Intensity Silviculture" and "Low Impact Silviculture"?

11) Do the "Production Areas" include areas under the recent Plan or areas reserved for future Plans as well? 
12) Are there "areas of restoration" within the production areas?

13) To what extent does the community participate in the classification of land use?

14) Does the community have statutes for the regulation of the conservation areas? If not, are there any "informal rules"?

15) Does the community receive and Payment for Ecosystem Services (PES)? Is it certified under the Forest Stewardship Certification or any other certifications? Do you harvest any non-timber materials?

\section{Governance of Territory}

16) How many recognized comuneros are there?

17) To what extent do they participate in the elaboration of the Forest Management Plan?

18) Do you have the contact information for the Comisariado (Head of Communal

Resources)?

\section{Historic Timber Harvests}

19) If I'm interested in obtaining the data for the timber harvests from 1993 to 2013 to verify/validate whether, even though high volumes have been harvested, there are still high rates of forest cover, would you have those accessible?

20) What would you say about the level of deforestation/forest cover in the community since $1993 ?$

21) As far as you know, have many things changed in the management of the forest since the FMP was implemented? 
22) Would you say the communities' conservation practices today come from a preexisting "conservation consciousness"?

23) Why would you say communities generally log below the authorized volumes?

24) What do you believe could be done to improve the management of your forests further?

25 ) Is there anything you would like to add? 


\section{APPENDIX II:}

Translated questions from Interview with Comisariados

\section{General Info}

How long have you been Comisariado de Bienes Comunales for the community?

1) Are there disputes over boundaries? Yes No

2) Number of areas with land conflicts?

Conflict 1: Name of location

a. Area in dispute (ha)

b. Is the area forested? Yes No

c. Briefly describe the problem

Conflict 2 and 3: Same as above

\section{$\underline{\text { Social Data }}$}

3) How many comuneros live in the community (\#)?

4) How many comuneros live out of the community (\#)?

5) Calculate $\%$

6) How many children of comuneros are there?

7) How many of the comuneros children live outside the community (\#)?

\section{Land use}

8) Is there commercial agriculture? Yes No

9) How much surface area is used for commercial agriculture (ha)? 
10) What type(s) of commercial agriculture are there?

11) (If there is cultivation of corn) Is the area for growing corn expanding?

12) (If there is coffee) Is the area for the cultivation of coffee expanding?

13) Of the agricultural area, what percentage would you say are not being used for planting crops?

14) Are there grasslands? Yes No

15) How much surface area (ha) are grasslands?

16) What type of cattle is there in the community?

17a) How many heads of cattle are there in the community?

17b) Has that number increased or decreased?

18) Do you harvest non-timber products with permission?

19) How much surface area (ha)?

20) What types of non-timber products are being harvested?

21) Do you harvest non-timber products without a permit? Yes No

22) What area (ha)?

23) What types of non-timber products are being harvested without a permit?

24) That you know of, are there restoration areas being managed by the community, that are not a part of the management plan?

25) How are conservation areas determined in the forest?

\section{Economic Data}

26) What is the most important source of income?

27) What is the second most important source of income? 
28) What is the thirds most important source of income for households?

29) How many comuneros work for CFE?

30) How many individuals (non-comuneros) from neighboring areas work for CFE?

31) How many people form other communities work for CFE?

32) How many comuneros have maize field (milpa)?

33) How many comuneros have cash crops, for example coffee, etc. (indicate)?

34) How many comuneros have bees/hives?

35) How many comuneros work with non-timber products?

36) How many comuneros own cattle?

37) How many comuneros receive money transfers?

38) Are there annual profits from the sale of timber?

39) If there are annual profits, are they distributed to: Comunero/Community funds/

Other Methods

39b) How are they distributed (\%)?

40) Is the community under Payments for Environmental Services contracts with CONAFOR?

41) If yes, what form of payment do they receive? Hydrologic / Biodiversity/ Carbon/ Agroforesty

42) How are the economic resources of environmental services used in the community?

43) Have comuneros been trained to manage fire?

44) If so, who trained them?

45a) In your opinion, is there any pressure to reduce the amount of forested area?

45b) If so, what type? 
46) Are there any conflicts within the community related to forestry?

47) If the answer is yes, do you consider conflicts to be: (Serious) (Not very serious) (Not serious/not related)

48) Could you explain what these conflicts consist of?

49) In your opinion, how much does the community participate in program development?

50) Does the community have a say on the volume of timber allowed to be harvested? 